\title{
UK Renal Registry 15th Annual Report: Chapter 6 Haemoglobin, Ferritin and Erythropoietin Amongst UK Adult Dialysis Patients in 2011: National and Centre-Specific Analyses
}

\author{
Anirudh Rao ${ }^{a}$, Julie Gilg ${ }^{a}$, Andrew Williams ${ }^{b}$ \\ aUK Renal Registry, Bristol, UK; ${ }^{\mathrm{b}}$ Morriston Hospital, Swansea, UK
}

\section{Key Words}

Anaemia · Chronic kidney disease · Dialysis - End stage renal disease · Epidemiology · Erythropoietin - Erythropoietin stimulating agent - European Best Practice Guidelines . Ferritin - Haemodialysis - Haemoglobin - NICE - Peritoneal dialysis · Renal Association

\footnotetext{
Abstract

Background: The UK Renal Association (RA) and National Institute for Health and Care Excellence (NICE) have published Clinical Practice Guidelines which include recommendations for management of anaemia in established renal failure. Aims: To determine the extent to which the guidelines for anaemia management are met in the UK. Methods: Quarterly data were obtained for haemoglobin $(\mathrm{Hb})$ and factors that influence $\mathrm{Hb}$ from renal centres in England, Wales, Northern Ireland $(\mathrm{E}, \mathrm{W}, \mathrm{NI})$ and the Scottish Renal Registry for the incident and prevalent
}

renal replacement therapy (RRT) cohorts for 2011. Results: In the UK, in $201151 \%$ of patients commenced dialysis therapy with $\mathrm{Hb} \geqslant 10.0 \mathrm{~g} / \mathrm{dl}$ (median $\mathrm{Hb} 10 \mathrm{~g} / \mathrm{dl}$ ). Of patients in the early presentation group, $55 \%$ started dialysis with $\mathrm{Hb} \geqslant 10.0 \mathrm{~g} / \mathrm{dl}$ whilst $37 \%$ of patients presenting late started dialysis with $\mathrm{Hb} \geqslant 10.0 \mathrm{~g} / \mathrm{dl}$. The UK median $\mathrm{Hb}$ of haemodialysis (HD) patients was $11.2 \mathrm{~g} / \mathrm{dl}$ with an inter-quartile range (IQR) of $10.3-12.1 \mathrm{~g} / \mathrm{dl}$. Of UK HD patients, $82 \%$ had $\mathrm{Hb} \geqslant 10.0 \mathrm{~g} / \mathrm{dl}$. The median $\mathrm{Hb}$ of peritoneal dialysis (PD) patients in the UK was $11.4 \mathrm{~g} / \mathrm{dl}$ (IQR 10.5$12.3 \mathrm{~g} / \mathrm{dl}$ ). Of UK PD patients, $85 \%$ had $\mathrm{Hb} \geqslant 10.0 \mathrm{~g} / \mathrm{dl}$. The median ferritin in HD patients in the UK was $436 \mu \mathrm{g} / \mathrm{L}$ (IQR $292-625)$ and $96 \%$ of HD patients had a ferritin $\geqslant 100 \mu \mathrm{g} /$ L. In EW\&NI the median ferritin in PD patients was $273 \mu \mathrm{g} /$ L (IQR 153-446) with $86 \%$ of PD patients having a ferritin $\geqslant 100 \mu \mathrm{g} / \mathrm{L}$. In EW\&NI the mean erythropoietin stimulating agent (ESA) dose was higher for HD than PD patients (8,740 vs. 6,624 IU/week). Conclusions: Prevalent HD and PD patients had $56 \%$ and $53 \%$ respectively within the $\mathrm{Hb}$ $\geqslant 10$ and $\leqslant 12 \mathrm{~g} / \mathrm{dl}$ target.

\section{KARGER}

Fax +4161306 1234 E-Mail karger@karger.ch www.karger.com 


\section{Introduction}

This chapter describes the UK Renal Registry (UKRR) data relating to the management of anaemia in dialysis patients during 2011. The chapter reports outcomes of submitted variables and analyses of these variables in the context of the UK Renal Association - Anaemia in CKD guidelines and recommendations.

In this report haemoglobin levels are given in $\mathrm{g} / \mathrm{dl}$ as the majority of UK laboratories were using these units in 2011. It is intended to switch to reporting haemoglobin levels in $\mathrm{g} / \mathrm{L}$ in the 16th annual report.

Anaemia in adults with CKD is diagnosed when the $\mathrm{Hb}$ concentration is $<13.0 \mathrm{~g} / \mathrm{dl}$ in males and $<12.0 \mathrm{~g} / \mathrm{dl}$ in females [1]. The degree of renal impairment affects the likelihood of any patient developing anaemia. Although current treatment with ESAs is not recommended unless $\mathrm{Hb}$ falls consistently below $11.0 \mathrm{~g} / \mathrm{dl}$, other causes of anaemia should be excluded in patients with $\mathrm{Hb}$ below normal range.

The renal National Service Framework (NSF) part one [2] and the RA minimum standards document 3rd edition [3] state that individuals with chronic kidney disease (CKD) should achieve a haemoglobin $(\mathrm{Hb})$ of at least $10 \mathrm{~g} / \mathrm{dl}$ within six months of being seen by a nephrologist, unless there is a specific reason why it was unachievable. At present the UKRR does not collect $\mathrm{Hb}$ measurements specifically from patients six months after meeting a nephrologist. However, an indication of the attainment of this standard is given by the $\mathrm{Hb}$ of the incident patient population at the start of dialysis. The achievement of these standards is mainly through the use of iron therapy (oral and intravenous) and erythropoietin stimulating agents (ESAs).

The European Best Practice Guidelines (EBPG) [4] set a minimum target of $11 \mathrm{~g} / \mathrm{dl}$ but suggest not to go higher than $12 \mathrm{~g} / \mathrm{dl}$ in severe cardiovascular disease. The United States Kidney Disease Outcomes Quality Initiative (KDOQI) [5] guidelines set a target $\mathrm{Hb}$ range of 11$12 \mathrm{~g} / \mathrm{dl}$ with a recommendation that the $\mathrm{Hb}$ target should not be greater than $13.0 \mathrm{~g} / \mathrm{dl}$. The NICE guidelines published in 2006 [6] and the 4th edition of the RA Clinical Practice Guidelines 2006 [7] recommended an outcome $\mathrm{Hb}$ of between 10.5 and $12.5 \mathrm{~g} / \mathrm{dl}$ (with ESA dose changes considered at 11 and $12 \mathrm{~g} / \mathrm{dl}$ ) to allow for the difficulty in consistently narrowing the distribution to between 11 and $12 \mathrm{~g} / \mathrm{dl}$. In 2009, a new target $\mathrm{Hb}$ range for haemodialysis (HD) patients was recommended by the 5th edition of the Renal Association Guidelines for Haemodialysis patients [8]. This guidance specified that
pre-HD $\mathrm{Hb}$ concentration should be maintained between 10 and $12 \mathrm{~g} / \mathrm{dl}$. The 5th edition of the UK Renal Association's Anaemia in CKD guideline was published at the end of 2010 and attempted to unify targets with those published in the 2010 update NICE guideline on anaemia management in CKD [9]. The target outcome $\mathrm{Hb}$ for RRT patients on ESA treatment in these guidelines is between 10 and $12 \mathrm{~g} / \mathrm{dl}$. The rationale behind choosing a wide target $\mathrm{Hb}$ range $(10-12 \mathrm{~g} / \mathrm{dl})$ is that when the target $\mathrm{Hb}$ level is narrow (e.g. $1 \mathrm{~g} / \mathrm{dl}$ ), variability in achieved $\mathrm{Hb}$ levels around the target is high, the fraction of prevalent patients with achieved $\mathrm{Hb}$ levels within the target range is low and ESA dose titration is required frequently during maintenance therapy. Therefore, as this chapter analyses 2011 data, this revised target has been used for both HD and PD patients. There are also some analyses showing attainment of the minimum standard of $\mathrm{Hb}$ $\geqslant 10.0 \mathrm{~g} / \mathrm{dl}$. The KDIGO website [10] is a useful resource for comparison of international anaemia guidelines.

In patients on peritoneal dialysis (PD), the timing of the blood sample draw is not critical because plasma volume in these patients remains relatively constant. In haemodialysis (HD) patients, interdialytic weight gain contributes to a decrease in $\mathrm{Hb}$ level, whereas intradialytic ultrafiltration leads to an increase in $\mathrm{Hb}$ level. Thus, a predialysis sample underestimates the euvolaemic $\mathrm{Hb}$ level, whereas a postdialysis sample overestimates the euvolaemic $\mathrm{Hb}$. Given the relationship between $\mathrm{Hb}$ level and the dialysis related weight change, midweek pre-dialysis sampling should be optimal for regular $\mathrm{Hb}$ monitoring [11].

The national and international recommendations for target iron status in CKD used in this chapter remain unchanged from the 2006 UKRR Annual Report. The 2007 Renal Association (RA) Clinical Practice Guidelines document, revised European Best Practice Guidelines (EBPGII), Dialysis Outcomes Quality Initiative (DOQI) guidelines and UK NICE anaemia guidelines all recommend a target serum ferritin greater than $100 \mu \mathrm{g} / \mathrm{L}$ and percentage transferrin saturation (TSAT) of more than $20 \%$ in patients with CKD. RA guidelines and EBPGII recommend hypochromic red cells (HRC) less than $10 \%$. In addition, EBPGII recommends target reticulocyte $\mathrm{Hb}$ content $(\mathrm{CHr})$ of greater than $29 \mathrm{pg} / \mathrm{cell}$. KDOQI recommends a serum ferritin $>200 \mu \mathrm{g} / \mathrm{L}$ for HD patients. The NICE guidelines suggest that a hypochromic red cell value $>6 \%$ indicates ongoing iron deficiency.

To achieve adequate iron status across a patient population, RA guidelines advocate population target 
medians for ferritin of $200-500 \mu \mathrm{g} / \mathrm{L}$ in HD patients and $100-500 \mu \mathrm{g} / \mathrm{L}$ for PD patients, for TSAT of $30-40 \%$, for hypochromic red cells of $<2.5 \%$ and $\mathrm{CHr}$ of $35 \mathrm{pg} /$ cell. EBPGII comments that a serum ferritin target for the treatment population of $200-500 \mu \mathrm{g} / \mathrm{L}$ ensures that $85-$ $90 \%$ of patients attain a serum ferritin of $100 \mu \mathrm{g} / \mathrm{L}$.

All guidelines advise that serum ferritin levels should not exceed $800 \mu \mathrm{g} / \mathrm{L}$ since the potential risk of toxicity increases without conferring additional benefit. The KDOQI and NICE guidelines advise against intravenous iron administration to patients with a ferritin $>500 \mu \mathrm{g} / \mathrm{L}$.

Serum ferritin has some disadvantages as an index of iron status. It measures storage iron rather than available iron, behaves as an acute phase reactant and is therefore increased in inflammatory states, malignancy and liver disease and may not accurately reflect iron stores if measured within a week of the administration of intravenous iron. Serum ferritin level is less reliable in the evaluation of iron stores in HD patients, because ferritin level is affected by other factors in addition to iron storage status. In relatively healthy HD patients, before widespread use of IV iron therapy, the finding of a ferritin level less than $50 \mathrm{ng} / \mathrm{mL}$ was not uncommon and was associated with absent bone marrow iron in approximately $80 \%$ of patients. However, in HD patients with several comorbidities, absent iron stores may still be found at ferritin levels approaching or even exceeding $200 \mathrm{ng} / \mathrm{mL}$ [12].

Of the alternative measures of iron status available, $\mathrm{HRC}$ and $\mathrm{CHr}$ are generally considered superior to TSAT. Both however require specialised analysers to which not all UK renal centres have easy access. Since TSAT is measured infrequently in many centres and most UK centres continue to use serum ferritin for routine iron management, ferritin remains the chosen index of iron status for this report.

Treatment of renal anaemia with ESAs has offered a major way to improve quality of life for dialysis patients. These agents are relatively expensive and thus approaches to achieving normal haemoglobin levels with the lowest possible doses are desirable. The health economics of anaemia therapy using ESAs has been subject to a NICE systematic review which concludes that treating to a target $\mathrm{Hb} 11-12 \mathrm{~g} / \mathrm{dl}$ is cost effective in HD patients.

The risks associated with low $(<10 \mathrm{~g} / \mathrm{dl})$ and high $(>13 \mathrm{~g} / \mathrm{dl}) \mathrm{Hb}$ are not necessarily equivalent. Two important studies of patients not yet on dialysis - CHOIR [13] and CREATE [14] showed an increased risk among the patients assigned to the higher $\mathrm{Hb}$ targets and adverse cardiovascular events. In the TREAT study [15] although there was no difference between the two arms in the primary outcome of death, cardiovascular event or end stage renal disease, there was an increase in fatal or nonfatal stroke in the treatment arm.

\section{Methods}

The incident and prevalent RRT cohorts for 2011 were analysed. The UKRR extracted quarterly data electronically from renal centres in England, Wales and Northern Ireland; data from Scotland were provided by the Scottish Renal Registry.

For the analyses of $\mathrm{Hb}$ for incident patients, those patients commencing RRT on PD or HD were included whilst those receiving a pre-emptive transplant were excluded. Hb measurements from after starting dialysis but still within the same quarter of the year were used. Therefore, depending on when in the quarter a patient started RRT the $\mathrm{Hb}$ could be from 0 to 90 days later. The haemoglobin values the registry receives from the renal systems should be the closest available measurement to the end of the quarter. Patients who died within the first 90 days on treatment were excluded. Results are also shown with the cohort subdivided into early and late presenters (date first seen by a nephrologist more or less than 90 days respectively).

For the analyses of prevalent patients, those patients receiving dialysis on 31st December 2011 were included if they had been on the same modality of dialysis in the same centre for at least three months. In order to improve completeness the last available measurement for each patient from the last two quarters for $\mathrm{Hb}$ and from the last three quarters for ferritin was used. Scotland was excluded from the analysis for ferritin for PD patients as this data was not available.

The completeness of data items was analysed at both centre and country level. As in previous years all patients were included in analyses but centres with less than $50 \%$ completeness were excluded from the caterpillar and funnel plots showing centre performance. Centres providing relevant data from less than 20 patients (10 patients for the analyses of incident patients) were also excluded from the plots. The number preceding the centre name in the caterpiller plots indicates the percentage of data that was missing for that centre.

The data were analysed to calculate summary statistics including maximum, minimum and average (mean and median) values. Standard deviations and inter-quartile ranges (IQR) were also calculated. These are shown using caterpillar plots giving median values and the inter-quartile ranges.

The percentages achieving RA and other standards were calculated for $\mathrm{Hb}$ and ferritin. These are displayed using caterpillar plots with the percentages meeting the targets and 95\% confidence intervals (CIs) shown. Funnel plots show the distribution of the percentages meeting the various targets and also whether any of the centres are significantly different from the average.

Longitudinal analysis was performed to show overall changes in achievement of standards from 1998 to 2011.

Erythropoietin data from the last quarter of 2011 were used to define which patients were receiving ESAs. Scotland was excluded from this analysis as data regarding ESA was not included in its return. Each individual was defined as being on ESA if a drug type and/or a dose was present in the data. Centres reporting fewer than $70 \%$ of HD patients or fewer than $50 \%$ of PD patients 
being treated with ESAs were considered to have incomplete data and were excluded from further analysis. It is recognised that these exclusion criteria are relatively arbitrary but they are in part based upon the frequency distribution graph of centres' ESA use as it appears in the data. The percentage of patients on ESAs is calculated from these data and incomplete data returns risk seriously impacting on any conclusions drawn.

For analyses of ESA dose, values are presented as weekly erythropoietin dose. Doses of less than $150 \mathrm{IU} /$ week (likely to be darbepoietin) were harmonised with erythropoietin data by multiplying by 200 . No adjustments were made with respect to route of administration.

Previous reports have only used the dose from the final quarter of the year. This year, starting with the cohort of patients receiving ESAs in the final quarter and having a dose value present for that quarter, any further dose values available from the earlier three quarters of the year (provided the patient was on the same treatment and receiving the same drug in those quarters) were used. The average (mean) of the available values was then used in analyses rather than the dose in the final quarter.

The ESA data were collected electronically from renal IT systems but in contrast to laboratory linked variables the ESA dose required manual data entry. The reliability depended upon the data source, whether the entry was linked to the prescription or whether the prescriptions were provided by the primary care physician. In the latter case, doses may not be as reliably updated as the link between data entry and prescription is indirect.

\section{Results}

\section{Anaemia management in incident dialysis patients}

Haemoglobin in incident dialysis patients

The $\mathrm{Hb}$ at the time of starting RRT gives the only indication of concordance with current anaemia management recommendations in the pre-dialysis (CKD 5 not yet on dialysis) group.

Patients for conservative care of established renal failure were by definition excluded from the dataset. Patients were similarly excluded if they received a preemptive transplant.

The percentage of data returned and outcome $\mathrm{Hb}$ are listed in table 6.1. Six centres were not included in this analysis due to either being small centres who submitted data on fewer than 10 patients and/or because data completeness was less than $50 \%$.

The median $\mathrm{Hb}$ of patients at the time of starting dialysis in the UK was $10.0 \mathrm{~g} / \mathrm{dl}$. The percentage of patients having a $\mathrm{Hb} \geqslant 10.0 \mathrm{~g} / \mathrm{dl}$ has fallen over the last couple of years to 51\% (53.6\% and 55\% for 2010 and 2009 cohorts respectively). The variation between centres remained high (25-74\%). Using only centres with presentation time data, the median $\mathrm{Hb}$ in the late presenters was $9.4 \mathrm{~g} / \mathrm{dl}$ with only $37 \%$ of patients having a $\mathrm{Hb}$ $\geqslant 10.0 \mathrm{~g} / \mathrm{dl}$ compared to a median $\mathrm{Hb}$ of $10.1 \mathrm{~g} / \mathrm{dl}$ and $55 \%$ of the patients having a $\mathrm{Hb} \geqslant 10.0 \mathrm{~g} / \mathrm{dl}$ in the early presenters group. In the late presenters group there was a large variation between centres in percentage of patients having a $\mathrm{Hb} \geqslant 10.0 \mathrm{~g} / \mathrm{dl}(0 \%-73 \%)$. The lower median $\mathrm{Hb}$ in late presenters may reflect inadequate pre-dialysis care with limited anaemia management, but alternatively, those presenting late may be more likely to have anaemia of multisystem disease or inter-current illness.

Median $\mathrm{Hb}$ of patients at dialysis start was also examined by modality and was $9.7 \mathrm{~g} / \mathrm{dl}$ (IQR $8.8-$ $10.7 \mathrm{~g} / \mathrm{dl}$ ) and $10.9 \mathrm{~g} / \mathrm{dl}$ (IQR 9.9-11.9 g/dl) for HD and PD patients respectively. When initiating dialysis, $44.5 \%$ of $\mathrm{HD}$ patients had a $\mathrm{Hb} \geqslant 10.0 \mathrm{~g} / \mathrm{dl}$, compared with $74.0 \%$ of $\mathrm{PD}$ patients.

The median starting $\mathrm{Hb}$ by centre is shown in figure 6.1 and the percentage starting with a $\mathrm{Hb}$ $\geqslant 10.0 \mathrm{~g} / \mathrm{dl}$ by centre is given in figure 6.2 .

Incident dialysis patients from 2010 were followed for one year and the median haemoglobin (and percentage with a $\mathrm{Hb} \geqslant 10.0 \mathrm{~g} / \mathrm{dl}$ ) of survivors on the same treatment at the same centre after a year was calculated for each quarter. This was sub-analysed by modality and length of pre-RRT care (figures 6.3 and 6.4). $\mathrm{Hb}$ was higher in the second quarter on dialysis than the quarter of start reflecting the treatment administered. Over $80 \%$ of incident patients surviving to a year had $\mathrm{Hb} \geqslant 10 \mathrm{~g} / \mathrm{dl}$ regardless of the modality or the length of pre-RRT care.

The annual distribution of $\mathrm{Hb}$ in incident dialysis patients is shown in figure 6.5. Since 2006, the proportion of incident patients with $\mathrm{Hb} \geqslant 12 \mathrm{~g} / \mathrm{dl}$ has fallen from $17 \%$ to $10 \%$ and the proportion of patients with $\mathrm{Hb}<10.0 \mathrm{~g} / \mathrm{dl}$ has increased from $40 \%$ to $49 \%$.

\section{ESA by time on dialysis in early vs. late presenters}

Figure 6.6 shows that there was a relatively small difference betweeen early and late presenters in the percentage of patients receiving an ESA in the first quarter for both HD and PD patients. The differences disappear within six months of starting dialysis.

\section{Anaemia management in prevalent dialysis patients}

Compliance with data returns for haemoglobin and serum ferritin and percentages on ESA are shown for the 71 renal centres in the UK in tables 6.2 for both HD and PD patients. Completeness of data returns was generally good for $\mathrm{Hb}$ and ferritin. The percentages on ESA are shown as they appear in the data received by 
Table 6.1. Haemoglobin data for incident patients starting haemodialysis or peritoneal dialysis during 2011, both overall and by presentation time

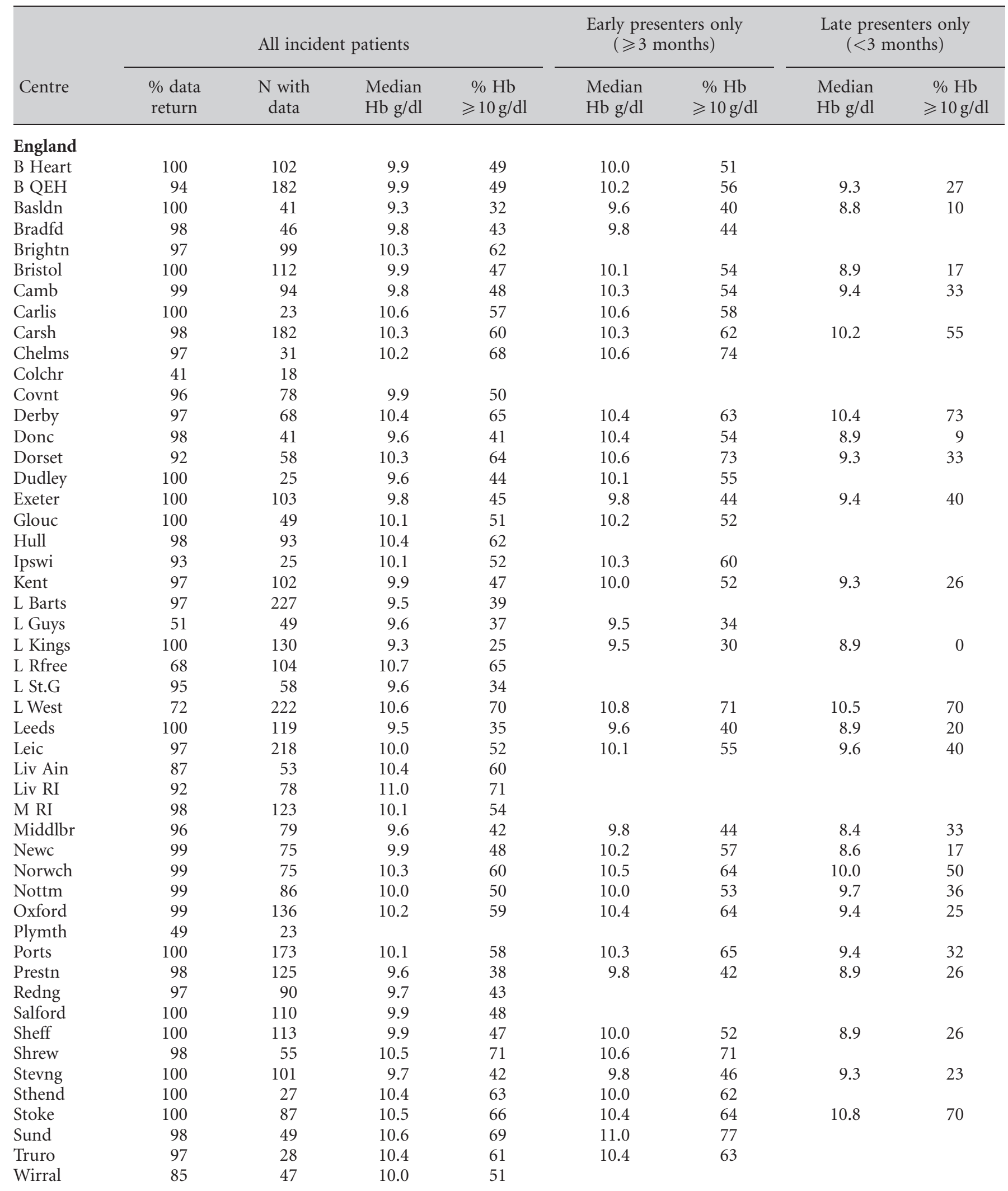


Table 6.1. Continued

\begin{tabular}{|c|c|c|c|c|c|c|c|c|}
\hline \multirow[b]{2}{*}{ Centre } & \multicolumn{4}{|c|}{ All incident patients } & \multicolumn{2}{|c|}{$\begin{array}{l}\text { Early presenters only } \\
\quad(\geqslant 3 \text { months })\end{array}$} & \multicolumn{2}{|c|}{$\begin{array}{l}\text { Late presenters only } \\
\qquad(<3 \text { months })\end{array}$} \\
\hline & $\begin{array}{l}\% \text { data } \\
\text { return }\end{array}$ & $\begin{array}{l}\mathrm{N} \text { with } \\
\text { data }\end{array}$ & $\begin{array}{l}\text { Median } \\
\text { Hb g/dl }\end{array}$ & $\begin{array}{l}\% \mathrm{Hb} \\
\geqslant 10 \mathrm{~g} / \mathrm{dl}\end{array}$ & $\begin{array}{l}\text { Median } \\
\mathrm{Hb} \text { g/dl }\end{array}$ & $\begin{array}{l}\% \mathrm{Hb} \\
\geqslant 10 \mathrm{~g} / \mathrm{dl}\end{array}$ & $\begin{array}{l}\text { Median } \\
\mathrm{Hb} \text { g/dl }\end{array}$ & $\begin{array}{c}\% \mathrm{Hb} \\
\geqslant 10 \mathrm{~g} / \mathrm{dl}\end{array}$ \\
\hline Wolve & 97 & 65 & 9.8 & 48 & 9.8 & 47 & 10.0 & 50 \\
\hline York & 100 & 38 & 9.6 & 34 & 9.6 & 41 & & \\
\hline Belfast & 89 & 47 & 9.9 & 47 & 9.6 & 42 & & \\
\hline Newry & 97 & 37 & 10.2 & 54 & 10.3 & 62 & & \\
\hline Ulster & 100 & 34 & 10.0 & 50 & 10.0 & 50 & & \\
\hline West NI & 97 & 30 & 10.3 & 57 & 10.5 & 57 & & \\
\hline \multicolumn{9}{|l|}{ Scotland } \\
\hline Dunfn & 58 & 23 & 10.3 & 65 & & & & \\
\hline Edinb & 80 & 49 & 10.4 & 59 & & & & \\
\hline Glasgw & 49 & 72 & & & & & & \\
\hline Inverns & 31 & 4 & & & & & & \\
\hline Klmarnk & 50 & 15 & 9.2 & 47 & & & & \\
\hline \multicolumn{9}{|l|}{ Wales } \\
\hline Bangor & 100 & 19 & 10.7 & 74 & 10.9 & 82 & & \\
\hline Cardff & 99 & 160 & 10.1 & 56 & 10.1 & 57 & 9.9 & 42 \\
\hline Clwyd & 100 & 6 & & & & & & \\
\hline Swanse & 97 & 101 & 10.1 & 51 & 10.1 & 56 & 9.3 & 32 \\
\hline Wrexm & 100 & 21 & 10.5 & 67 & 10.5 & 67 & & \\
\hline England & 93 & 4,535 & 10.0 & 51 & 10.1 & 55 & 9.4 & 37 \\
\hline
\end{tabular}

Blank cells - centres excluded from analyses due to poor data completeness or low patient numbers or because presentation time data not available

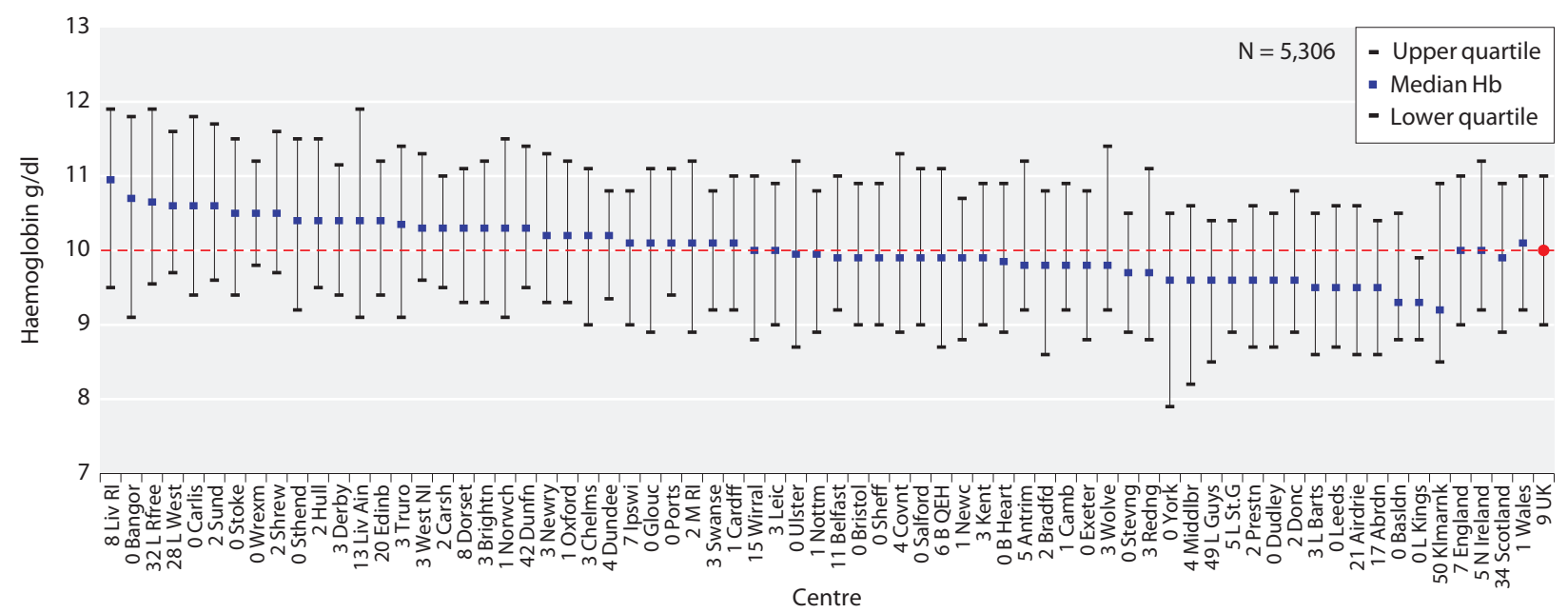

Fig. 6.1. Median haemoglobin for incident dialysis patients at start of dialysis treatment in 2011 


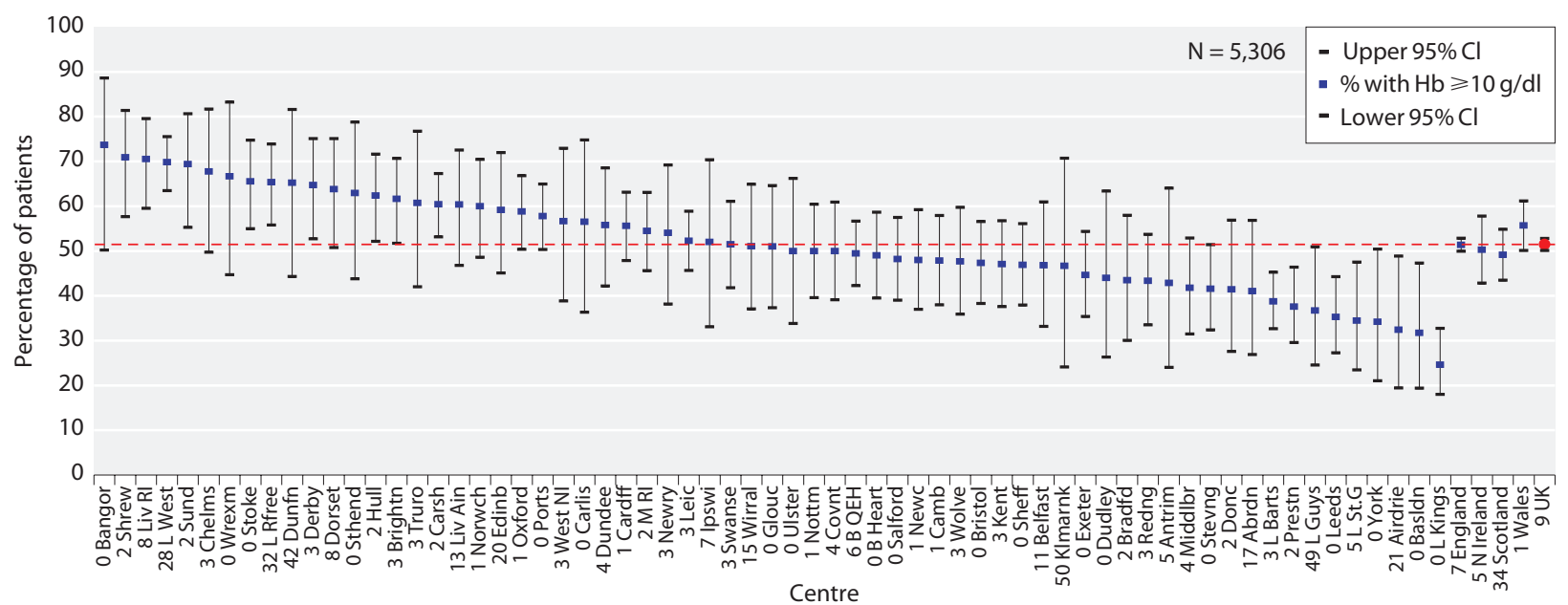

Fig. 6.2. Percentage of incident dialysis patients with $\mathrm{Hb} \geqslant 10 \mathrm{~g} / \mathrm{dl}$ at start of dialysis treatment in 2011

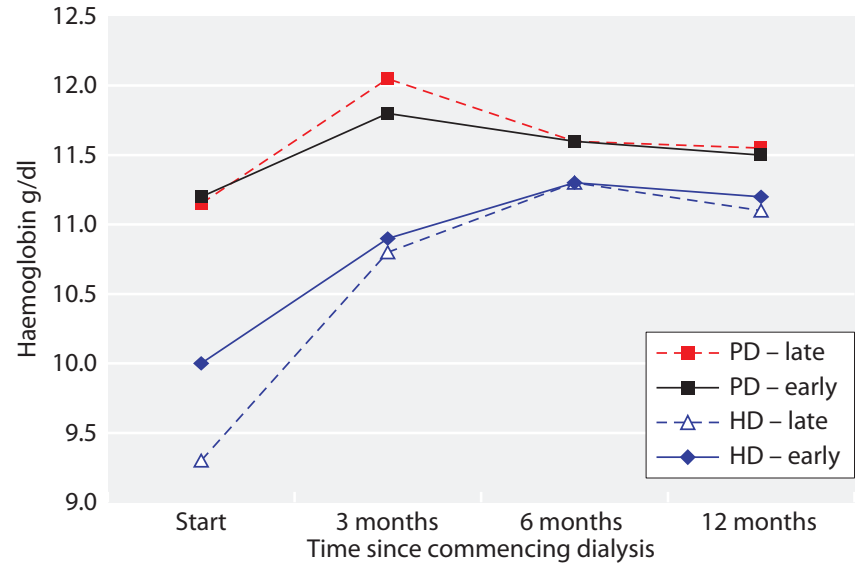

Fig. 6.3. Median haemoglobin, by time on dialysis and length of pre-RRT care, for incident dialysis patients in 2010

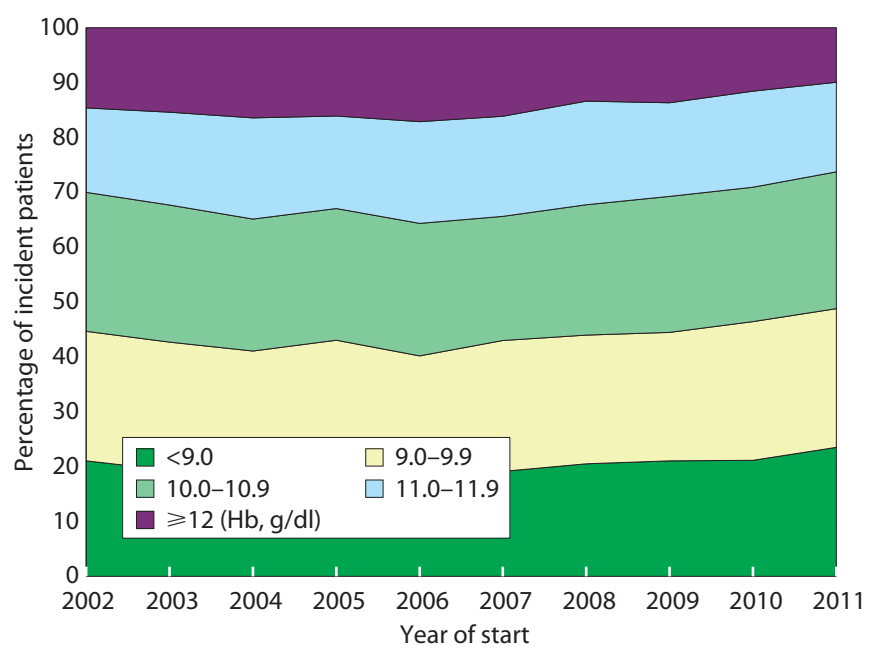

Fig. 6.5. Distribution of haemoglobin in incident dialysis patients by year of start

Anaemia Management in UK Dialysis Patients

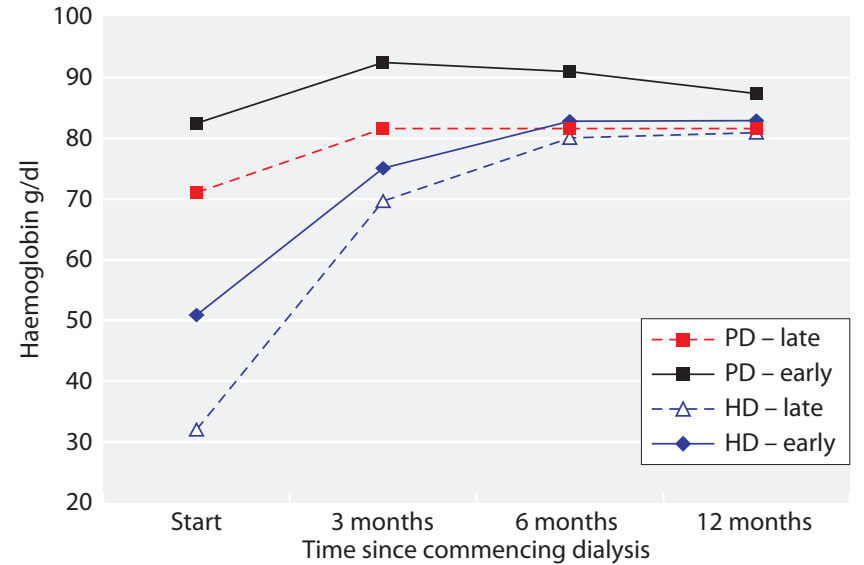

Fig. 6.4. Percentage of incident dialysis patients in 2010 with $\mathrm{Hb}$ $\geqslant 10 \mathrm{~g} / \mathrm{dl}$, by time on dialysis and by length of pre-RRT care

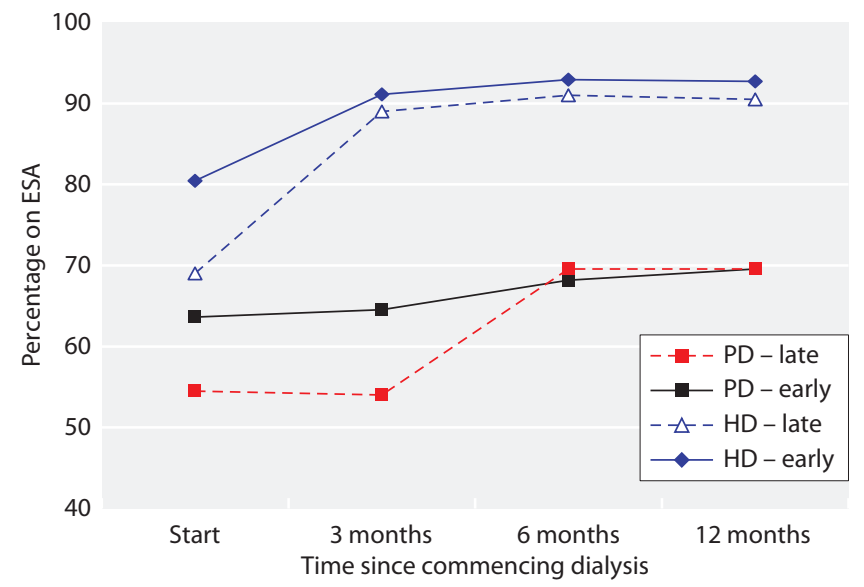

Fig. 6.6. Percentage of incident dialysis patients in 2010 on ESA, by time on dialysis and by length of pre-RRT care

Nephron Clin Pract 2013;123(suppl1):125-150 
Table 6.2. Percentage compliance for data returns for haemoglobin and serum ferritin and percentages on ESA for prevalent HD and PD patients in 2011

\begin{tabular}{|c|c|c|c|c|c|c|c|c|}
\hline \multirow{2}{*}{ Centre } & \multicolumn{4}{|c|}{$\mathrm{HD}$} & \multicolumn{4}{|c|}{$\mathrm{PD}$} \\
\hline & \multicolumn{3}{|c|}{$\%$ completeness } & $\%$ on ESA & $\mathrm{N}$ & \multicolumn{2}{|c|}{$\%$ completeness } & $\%$ on ESA \\
\hline \multicolumn{9}{|l|}{ England } \\
\hline B Heart & 413 & 100 & 99 & 76 & 38 & 100 & 100 & 61 \\
\hline Bradfd & 181 & 99 & 97 & 95 & 28 & 96 & 96 & 79 \\
\hline Brightn & 313 & 99 & 93 & 0 & 66 & 98 & 88 & 0 \\
\hline Bristol & 445 & 100 & 100 & 93 & 60 & 100 & 98 & 70 \\
\hline Camb & 334 & 99 & 87 & 15 & 32 & 100 & 100 & 72 \\
\hline Carlis & 60 & 100 & 93 & 60 & 17 & 100 & 100 & 59 \\
\hline Derby & 193 & 99 & 99 & 0 & 101 & 100 & 100 & 0 \\
\hline Donc & 153 & 100 & 97 & 92 & 21 & 100 & 100 & 76 \\
\hline Dorset & 222 & 100 & 98 & 3 & 45 & 100 & 98 & 9 \\
\hline Dudley & 137 & 100 & 99 & 4 & 50 & 98 & 84 & 8 \\
\hline Exeter & 340 & 100 & 99 & 96 & 63 & 100 & 100 & 76 \\
\hline Glouc & 183 & 100 & 96 & 94 & 34 & 94 & 91 & 62 \\
\hline Hull & 308 & 99 & 98 & 0 & 78 & 96 & 92 & 0 \\
\hline Ipswi & 119 & 100 & 67 & 86 & 30 & 100 & 93 & 87 \\
\hline Kent & 353 & 100 & 98 & 90 & 61 & 100 & 100 & 3 \\
\hline L Barts & 818 & 99 & 98 & 0 & 152 & 98 & 97 & 0 \\
\hline L Guys & 578 & 84 & 77 & 21 & 28 & 100 & 100 & 11 \\
\hline L Kings & 431 & 100 & 99 & 0 & 77 & 99 & 99 & 0 \\
\hline Middlbr & 285 & 98 & 98 & 81 & 14 & 93 & 93 & 64 \\
\hline Newc & 239 & 100 & 100 & 76 & 41 & 100 & 100 & 2 \\
\hline Norwch & 291 & 100 & 98 & 92 & 48 & 100 & 100 & 58 \\
\hline Nottm & 385 & 100 & 100 & 90 & 74 & 100 & 100 & 68 \\
\hline Oxford & 374 & 100 & 99 & 91 & 82 & 100 & 100 & 82 \\
\hline Plymth & 124 & 44 & 97 & 29 & 40 & 83 & 93 & 70 \\
\hline Ports & 468 & 100 & 99 & 11 & 83 & 99 & 95 & 17 \\
\hline Prestn & 486 & 99 & 99 & 87 & 54 & 100 & 100 & 59 \\
\hline Redng & 245 & 100 & 100 & 96 & 74 & 99 & 99 & 3 \\
\hline Salford & 337 & 90 & 21 & 95 & 97 & 100 & 1 & 93 \\
\hline Sheff & 560 & 100 & 100 & 89 & 54 & 100 & 100 & 59 \\
\hline Shrew & 176 & 100 & 99 & 95 & 27 & 96 & 89 & 67 \\
\hline Stevng & 387 & 100 & 99 & 0 & 26 & 100 & 96 & 0 \\
\hline Sthend & 116 & 100 & 100 & 92 & 16 & 100 & 100 & 44 \\
\hline Stoke & 292 & 100 & 99 & 1 & 69 & 100 & 100 & 0 \\
\hline Sund & 162 & 100 & 96 & 96 & 13 & 100 & 92 & 69 \\
\hline Truro & 139 & 100 & 100 & 1 & 22 & 100 & 95 & 0 \\
\hline Wirral & 181 & 75 & 70 & 2 & 36 & 75 & 53 & 0 \\
\hline
\end{tabular}


Table 6.2. Continued

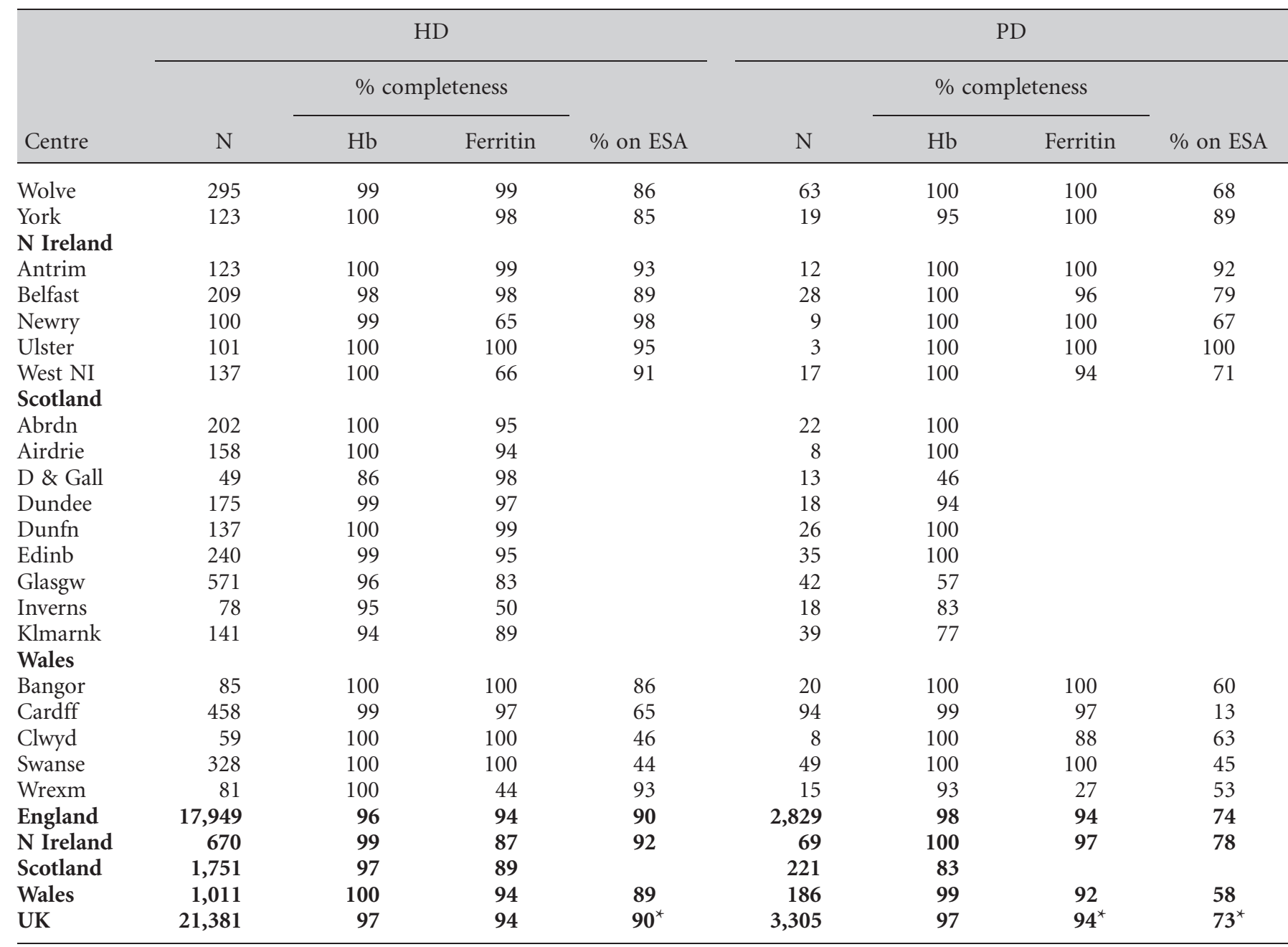

${ }^{*}$ The overall averages given are for $\mathrm{E}, \mathrm{W} \& \mathrm{NI}$ (not UK)

Blank cells - centres with no PD patients or because data not available

Percentages on ESA are shown, but it is believed that there were data problems for those centres with apparently less than $70 \%$ of HD patients or $50 \%$ of PD patients on ESA

The country level averages for the \% on ESA are based only on those centres whose \% was above the limits mentioned above

the registry. For some centres the ESA data is completely missing and for others it appears to be partially complete with, for example, only 10 or $20 \%$ of patients appearing to be on ESAs. It is believed that there were problems with data entry and/or data transfer in those centres with apparently less than $70 \%$ of HD patients or $50 \%$ of PD patients on ESA. These centres have been excluded from further analyses of ESA use.

Summary statistics for haemoglobin, serum ferritin and ESA are shown for the 71 renal centres in the UK in tables 6.3 for HD and 6.4 for PD patients respectively.
Haemoglobin in prevalent haemodialysis patients

The median $\mathrm{Hb}$ of patients on $\mathrm{HD}$ in the UK was $11.2 \mathrm{~g} / \mathrm{dl}$ with an IQR of $10.3-12.1 \mathrm{~g} / \mathrm{dl}$ and $82 \%$ of HD patients had a $\mathrm{Hb} \geqslant 10.0 \mathrm{~g} / \mathrm{dl}$ (table 6.3). The median $\mathrm{Hb}$ by centre is shown in figure 6.7. The UK median dropped from $11.5 \mathrm{~g} / \mathrm{dl}$ to $11.2 \mathrm{~g} / \mathrm{dl}$ between 2010 and 2011. Compliance with the target range of $\mathrm{Hb} \geqslant 10$ and $\leqslant 12 \mathrm{~g} / \mathrm{dl}$ increased from $52.7 \%$ in 2010 to $56.1 \%$ in 2011 (figure 6.8). The percentages of HD patients with $\mathrm{Hb}$ below $10 \mathrm{~g} / \mathrm{dl}$ and above $12 \mathrm{~g} / \mathrm{dl}$, as well as the percentages meeting the target, are shown by centre in figure 6.9.

Funnel plots are shown for the minimum $(\mathrm{Hb}$ 
Table 6.3. Summary statistics for haemoglobin, serum ferritin and ESA for prevalent HD patients in 2011

\begin{tabular}{|c|c|c|c|c|c|c|c|c|c|c|}
\hline Centre & $\begin{array}{l}\mathrm{N} \text { with } \\
\mathrm{Hb} \text { data }\end{array}$ & $\begin{array}{l}\text { Median } \\
\mathrm{Hb} \text { g/dl }\end{array}$ & $\begin{array}{c}\% \mathrm{Hb} \\
\geqslant 10 \mathrm{~g} / \mathrm{dl}\end{array}$ & $\begin{array}{c}\% \mathrm{Hb} \\
10-12 \mathrm{~g} / \mathrm{dl}\end{array}$ & $\begin{array}{c}\text { Median } \\
\text { ferritin } \\
\mu \mathrm{g} / \mathrm{L}\end{array}$ & $\begin{array}{c}\% \\
\text { ferritin } \\
\geqslant 100 \mu \mathrm{g} / \mathrm{L}\end{array}$ & $\begin{array}{l}\% \text { ferritin } \\
>200 \text { and } \\
\leqslant 500 \mu \mathrm{g} / \mathrm{L}\end{array}$ & $\begin{array}{l}\% \text { on } \\
\text { ESA }\end{array}$ & $\begin{array}{l}\text { Median } \\
\text { ESA dose } \\
\text { (IU/week) }\end{array}$ & $\begin{array}{l}\% \text { with } \mathrm{Hb} \\
\geqslant 10 \mathrm{~g} / \mathrm{dl} \text { and } \\
\text { not on ESA }\end{array}$ \\
\hline \multicolumn{11}{|l|}{ England } \\
\hline B Heart & 413 & 11.1 & 78 & 53 & 336 & 93 & 60 & 76 & 8,800 & 22 \\
\hline B QEH & 821 & 11.0 & 78 & 58 & 390 & 97 & 68 & 85 & 6,000 & 14 \\
\hline Basldn & 135 & 11.0 & 80 & 63 & 341 & 96 & 80 & 86 & 6,000 & 11 \\
\hline Brightn & 309 & 11.1 & 81 & 57 & 474 & 98 & 50 & & & \\
\hline Bristol & 445 & 11.3 & 82 & 56 & 599 & 97 & 29 & 93 & 7,500 & 7 \\
\hline Camb & 332 & 11.2 & 79 & 56 & 320 & 88 & 53 & & & \\
\hline Carlis & 60 & 11.6 & 88 & 53 & 482 & 100 & 54 & & & \\
\hline Carsh & 657 & 11.0 & 79 & 60 & 368 & 94 & 60 & & & \\
\hline Chelms & 113 & 11.1 & 77 & 54 & 449 & 100 & 57 & 98 & 10,000 & 1 \\
\hline Dorset & 222 & 11.4 & 85 & 54 & 495 & 98 & 46 & & & \\
\hline Dudley & 137 & 11.3 & 82 & 53 & 321 & 86 & 57 & & & \\
\hline Exeter & 340 & 11.1 & 81 & 56 & 278 & 96 & 71 & 96 & 7,789 & 4 \\
\hline Glouc & 183 & 11.4 & 90 & 66 & 384 & 95 & 49 & 94 & & 6 \\
\hline Hull & 305 & 11.5 & 90 & 58 & 411 & 99 & 65 & & & \\
\hline Ipswi & 119 & 11.4 & 86 & 55 & 624 & 98 & 26 & 86 & 7,625 & 12 \\
\hline Kent & 352 & 11.1 & 85 & 66 & 468 & 94 & 40 & 90 & 8,250 & 8 \\
\hline L Barts & 809 & 10.8 & 75 & 60 & 461 & 96 & 51 & & & \\
\hline L Guys & 485 & 10.9 & 77 & 59 & 554 & 98 & 34 & & & \\
\hline L Kings & 430 & 10.5 & 70 & 61 & 567 & 98 & 33 & & & \\
\hline L Rfree & 474 & 11.6 & 85 & 46 & 499 & 96 & 34 & & & \\
\hline Newc & 239 & 11.3 & 84 & 56 & 430 & 92 & 41 & 76 & 9,225 & 22 \\
\hline Norwch & 290 & 11.4 & 89 & 59 & 489 & 96 & 37 & 92 & 8,000 & 7 \\
\hline Nottm & 384 & 11.2 & 84 & 61 & 561 & 99 & 32 & 90 & 8,250 & 9 \\
\hline Oxford & 374 & 11.1 & 79 & 54 & 286 & 91 & 55 & 91 & 8,000 & 9 \\
\hline Plymth & 55 & & & & 734 & 98 & 25 & & & \\
\hline Ports & 468 & 11.5 & 86 & 49 & 313 & 94 & 59 & & & \\
\hline Prestn & 482 & 11.1 & 82 & 57 & 593 & 92 & 26 & 87 & & 12 \\
\hline Redng & 245 & 11.2 & 82 & 56 & 509 & 98 & 42 & 96 & & 4 \\
\hline Salford & 302 & 10.9 & 78 & 53 & & & & 95 & 6,000 & 3 \\
\hline Sheff & 560 & 11.2 & 81 & 52 & 491 & 97 & 45 & 89 & 7,500 & 10 \\
\hline Shrew & 176 & 11.5 & 91 & 59 & 394 & 95 & 58 & 95 & 7,500 & 5 \\
\hline Stevng & 387 & 11.3 & 83 & 58 & 432 & 97 & 49 & & & \\
\hline Sthend & 116 & 10.8 & 78 & 61 & 316 & 97 & 70 & 92 & 9,000 & 8 \\
\hline Stoke & 292 & 11.4 & 86 & 55 & 540 & 99 & 38 & & & \\
\hline Sund & 162 & 11.5 & 90 & 56 & 598 & 98 & 31 & 96 & 8,788 & 3 \\
\hline Truro & 139 & 11.0 & 81 & 65 & 507 & 99 & 47 & & & \\
\hline Wirral & 135 & 11.0 & 73 & 52 & 513 & 99 & 40 & & & \\
\hline Wolve & 293 & 11.4 & 87 & 55 & 466 & 97 & 52 & 86 & 6,000 & 13 \\
\hline York & 123 & 10.8 & 80 & 63 & 414 & 93 & 66 & 85 & 4,000 & 13 \\
\hline
\end{tabular}


Table 6.3. Summary statistics for haemoglobin, serum ferritin and ESA for prevalent HD patients in 2011

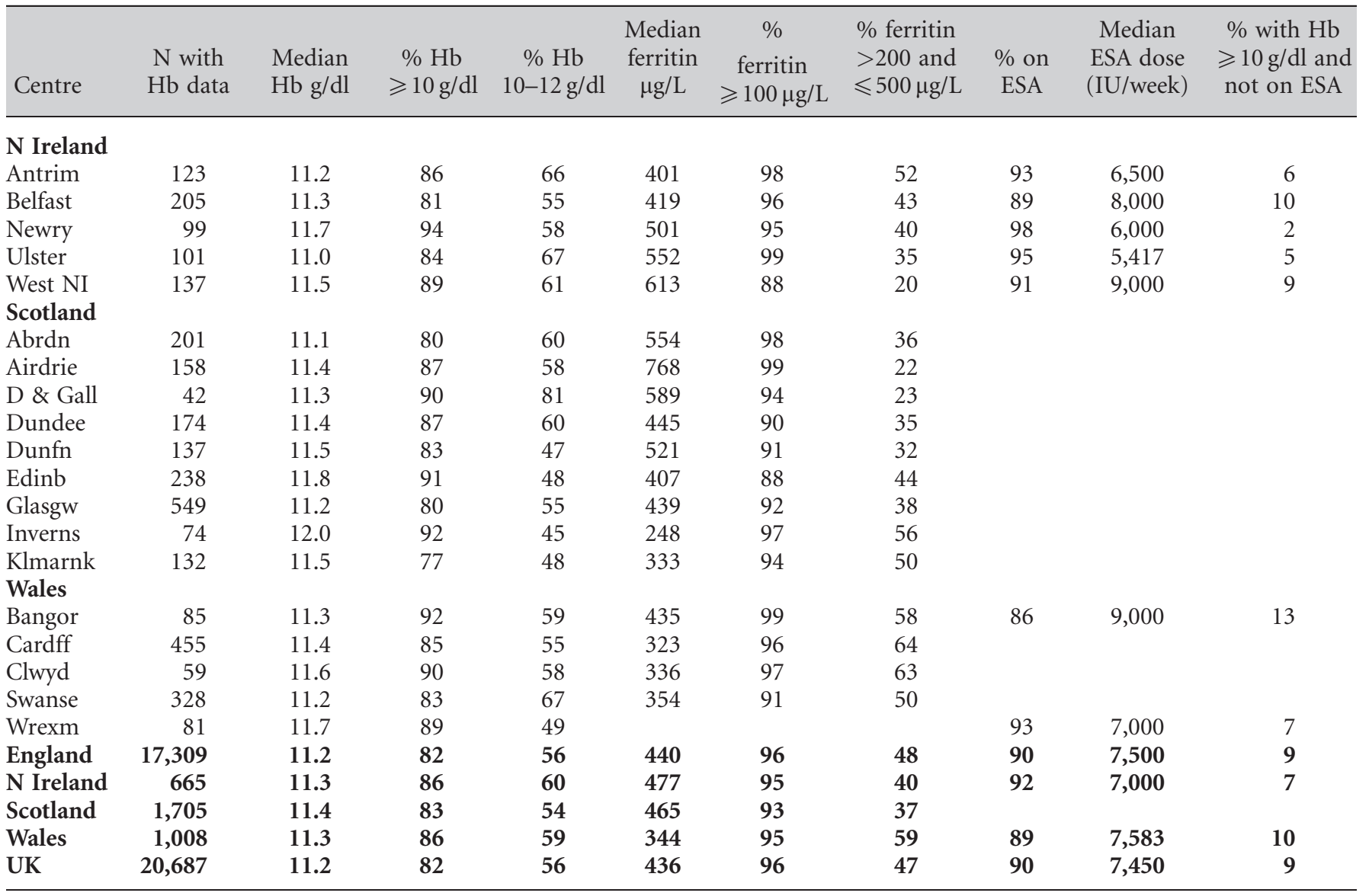

Blank cells - centres excluded from analyses due to poor data completeness or low patient numbers or because the data item was not available ESA data only shown for those centres for which the \% on ESA was $70 \%$ or more

For ESA the overall averages given are for E,W \& NI not UK

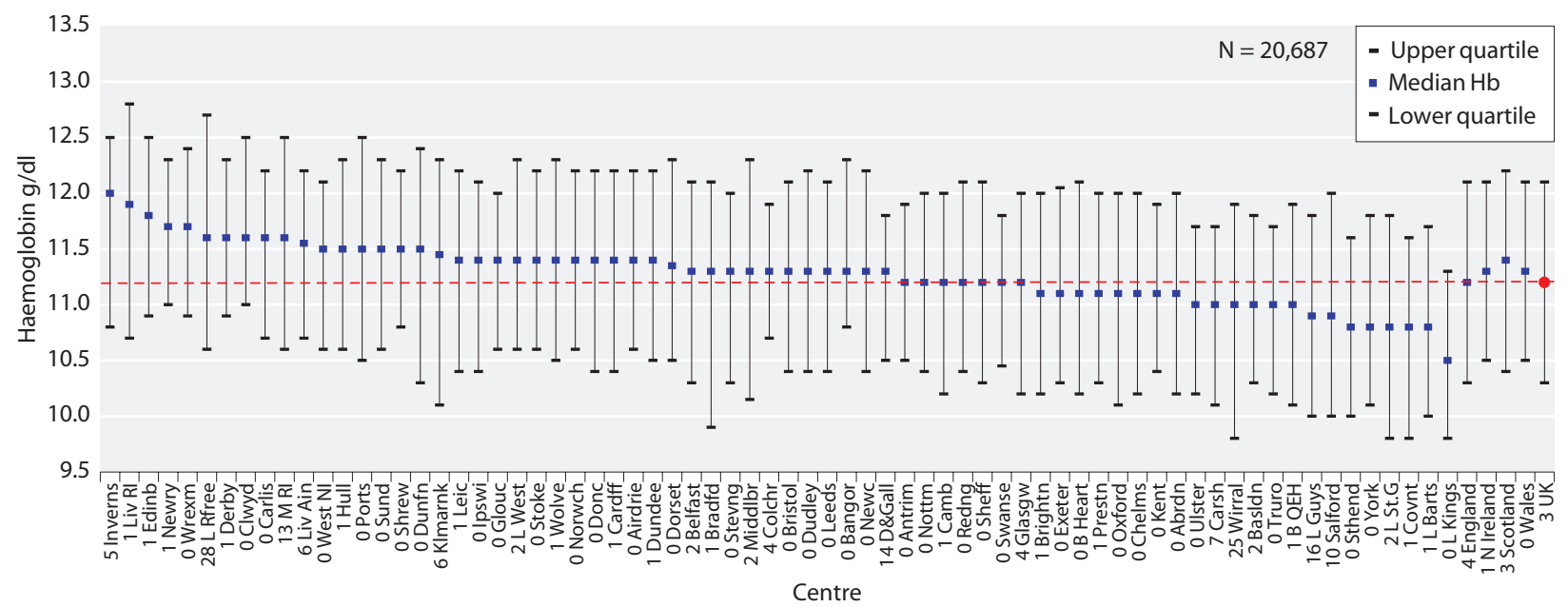

Fig. 6.7. Median haemoglobin in patients treated with HD by centre in 2011 


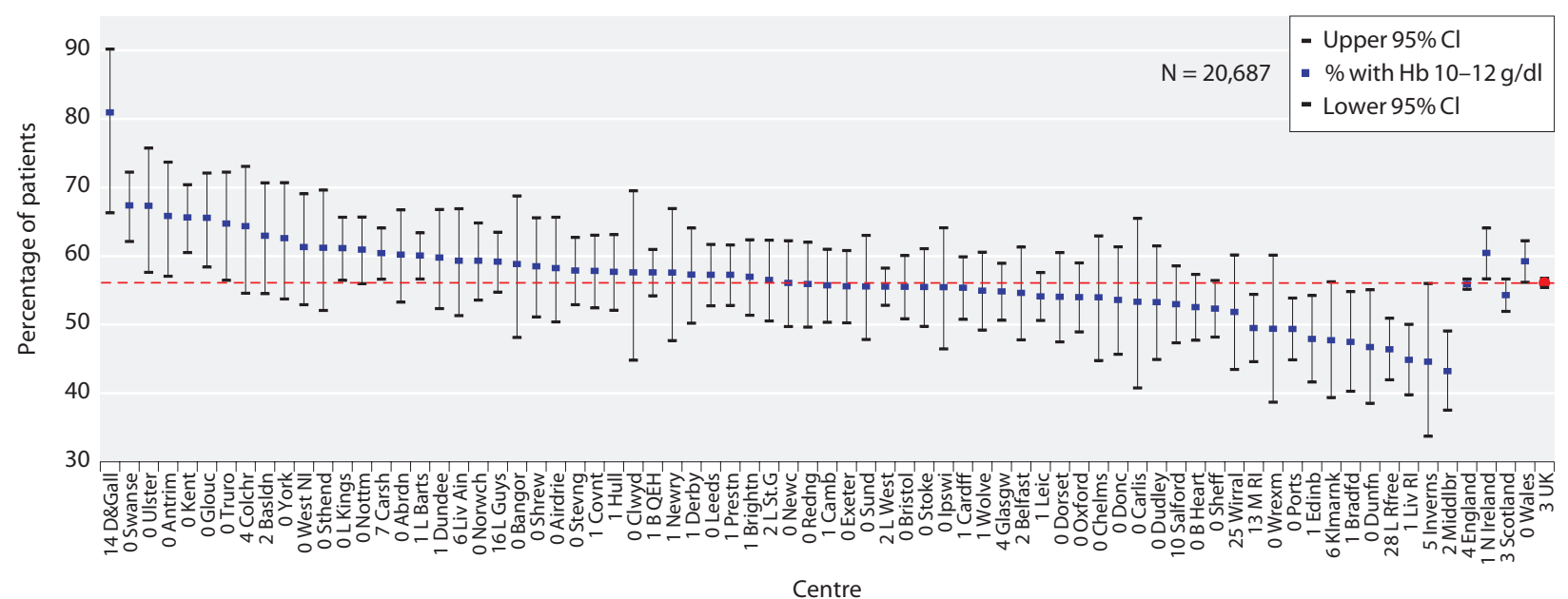

Fig. 6.8. Percentage of $\mathrm{HD}$ patients with $\mathrm{Hb} \geqslant 10$ and $\leqslant 12 \mathrm{~g} / \mathrm{dl}$ by centre in 2011

$\geqslant 10.0 \mathrm{~g} / \mathrm{dl})$ and target range $(\mathrm{Hb} \geqslant 10$ and $\leqslant 12 \mathrm{~g} / \mathrm{dl})$ in figures 6.10 and 6.11 respectively. Many centres complied well with respect to both the minimum and target range $\mathrm{Hb}$ standards. Some centres fell within 3 SDs of the mean in the funnel plot for the percentage of patients with $\mathrm{Hb}$ $\geqslant 10$ and $\leqslant 12 \mathrm{~g} / \mathrm{dl}$ (figure 6.11) and yet had a poor compliance with the percentage with $\mathrm{Hb} \geqslant 10.0 \mathrm{~g} / \mathrm{dl}$ (figure 6.10) (for example Coventry, London Barts and London Kings). On the contrary some centres complied well with the percentage with $\mathrm{Hb} \geqslant 10.0 \mathrm{~g} / \mathrm{dl}$ but had a poor compliance with percentage of patients with $\mathrm{Hb}$ $\geqslant 10$ and $\leqslant 12 \mathrm{~g} / \mathrm{dl}$ (for example London Royal Free and Liverpool Royal had 31-44\% of their patients with $\mathrm{Hb}>12.0 \mathrm{~g} / \mathrm{dl}$ ). This demonstrates that compliance with one standard can be achieved without compliance with another standard. Table 6.3 can be used in conjunction with figures 6.10 and 6.11 to identify centres.

\section{Haemoglobin in prevalent peritoneal dialysis patients}

Overall, $85 \%$ of patients on PD had a $\mathrm{Hb} \geqslant 10.0 \mathrm{~g} / \mathrm{dl}$ (table 6.4). The median $\mathrm{Hb}$ of patients on PD in the UK in 2011 was $11.4 \mathrm{~g} / \mathrm{dl}$ with an IQR of $10.5-12.3 \mathrm{~g} / \mathrm{dl}$ which compares with $11.6 \mathrm{~g} / \mathrm{dl}$ in 2010 . The median $\mathrm{Hb}$ by centre is shown in figure 6.12. The compliance with $\mathrm{Hb}$ $\geqslant 10.0$ and $\leqslant 12.0 \mathrm{~g} / \mathrm{dl}$ is shown in figure 6.13. In 2011, $53 \%$ of prevalent $\mathrm{PD}$ patients had a $\mathrm{Hb}$ within the target range. The distribution of $\mathrm{Hb}$ in $\mathrm{PD}$ patients by centre is shown in figure 6.14. The funnel plots for percentage with $\mathrm{Hb} \geqslant 10.0 \mathrm{~g} / \mathrm{dl}$ and for the percentage of patients with $\mathrm{Hb} \geqslant 10$ and $\leqslant 12 \mathrm{~g} / \mathrm{dl}$ are shown in

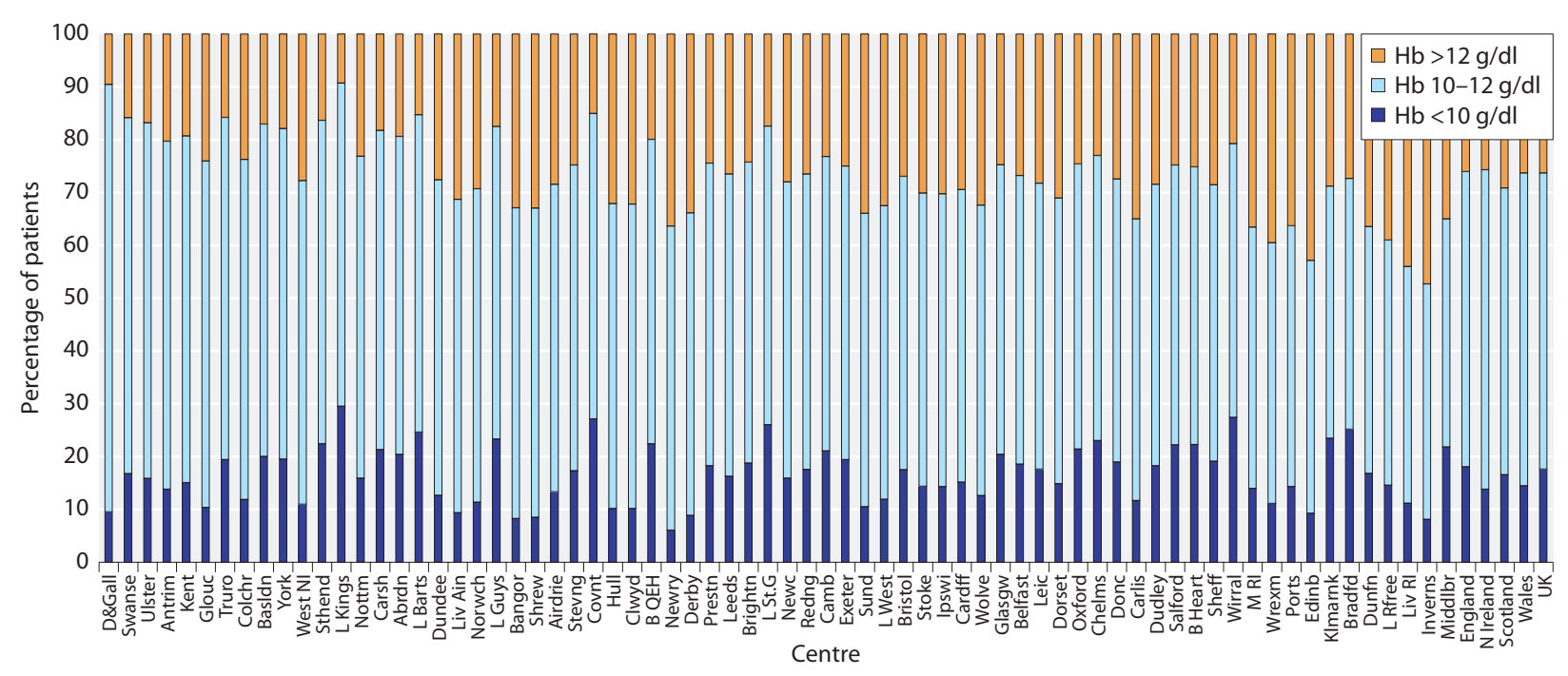

Fig. 6.9. Distribution of haemoglobin in patients treated with HD by centre in 2011 


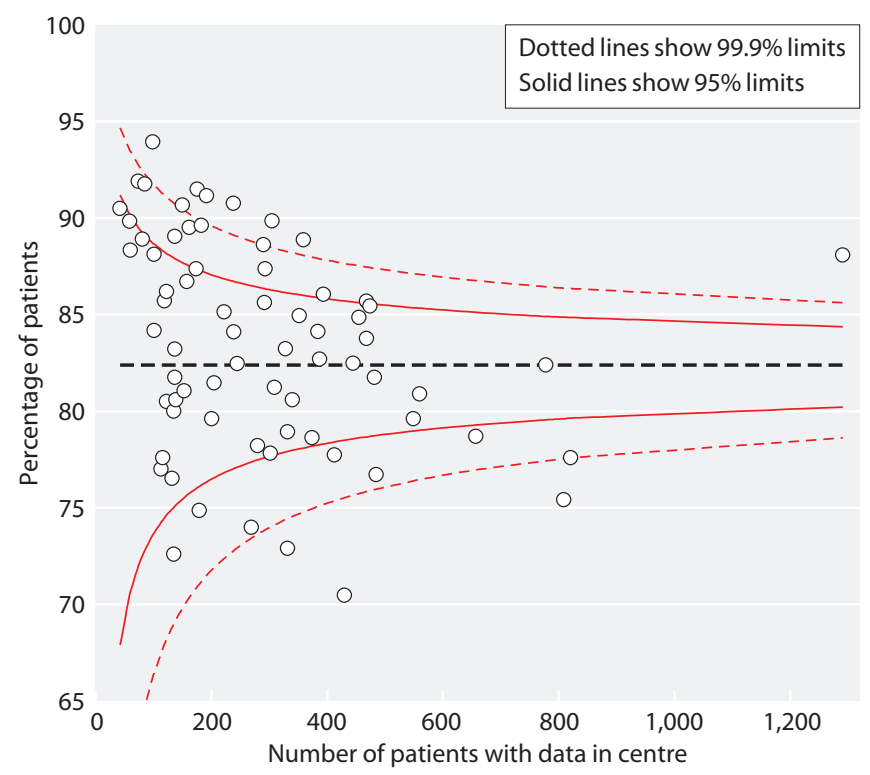

Fig. 6.10. Funnel plot of percentage of $\mathrm{HD}$ patients with $\mathrm{Hb}$ $\geqslant 10 \mathrm{~g} / \mathrm{dl}$ by centre in 2011

figures 6.15 and 6.16 respectively. Table 6.4 can be used in conjunction with figures 6.15 and 6.16 to identify centres in the funnel plot.

Relationship between $\mathrm{Hb}$ in incident and prevalent dialysis patients in 2011

The relationship between the percentage of incident and prevalent dialysis ( $\mathrm{HD}$ and $\mathrm{PD}$ ) patients with $\mathrm{a} \mathrm{Hb}$

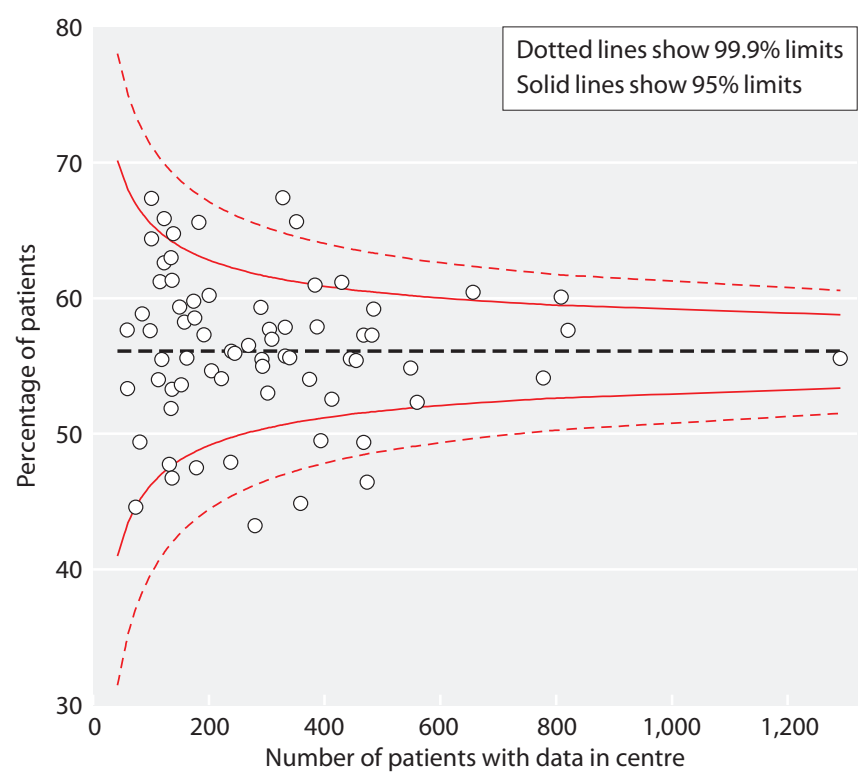

Fig. 6.11. Funnel plot of percentage of $\mathrm{HD}$ patients with $\mathrm{Hb} \geqslant 10$ and $\leqslant 12 \mathrm{~g} /$ dl by centre in 2011 $\geqslant 10.0 \mathrm{~g} / \mathrm{dl}$ is shown in figure 6.17. As expected, all centres had a higher percentage of prevalent patients achieving a $\mathrm{Hb} \geqslant 10.0 \mathrm{~g} / \mathrm{dl}$ than that for incident patients. Overall in the UK, $83 \%$ of prevalent patients, compared with $51 \%$ of incident patients, had a $\mathrm{Hb}$ $\geqslant 10.0 \mathrm{~g} / \mathrm{dl}$ in 2011. Compliance with 'current' minimum standards by year (1998-2011) for incident and prevalent patients (all dialysis patients) is shown in figure 6.18. Since 2006 there has been a decline in achieving this standard for incident and prevalent patients.

\section{Ferritin in prevalent haemodialysis patients}

The median and IQR for serum ferritin for patients treated with HD are shown in figure 6.19. The percentages with serum ferritin $\geqslant 100 \mu \mathrm{g} / \mathrm{L},>200 \mu \mathrm{g} / \mathrm{L}$ and $\leqslant 500 \mu \mathrm{g} / \mathrm{L}$, and $\geqslant 800 \mu \mathrm{g} / \mathrm{L}$ are shown in figures 6.20 , 6.21 and 6.22 respectively. Most centres achieved greater than $90 \%$ compliance with a serum ferritin $\geqslant 100 \mu \mathrm{g} / \mathrm{L}$ for HD patients. The HD population had a median ferritin value of $436 \mu \mathrm{g} / \mathrm{L}$, IQR 292-625. Twenty-one of the 69 units who had returns for ferritin had greater than $20 \%(21-43 \%)$ of their patients with ferritin $\geqslant 800 \mu \mathrm{g} / \mathrm{L}$ (figure 6.22). The serum ferritin correlated poorly with median $\mathrm{Hb}$ achieved and ESA dose demonstrating that serum ferritin is a poor index of iron status.

\section{Ferritin in prevalent peritoneal dialysis patients}

The median and IQR for serum ferritin for patients treated with PD are shown in figure 6.23. The percentages with serum ferritin $\geqslant 100 \mu \mathrm{g} / \mathrm{L},>100 \mu \mathrm{g} / \mathrm{L}$ and $\leqslant 500 \mu \mathrm{g} / \mathrm{L}$, and $\geqslant 800 \mu \mathrm{g} / \mathrm{L}$ are shown in figures 6.24 , 6.25 and 6.26 respectively. The PD population had a lower median ferritin value at $273 \mu \mathrm{g} / \mathrm{L}$, IQR 153-446. In 2011, 27 centres reported less than $90 \%$ of PD patients compliant with serum ferritin $\geqslant 100 \mu \mathrm{g} / \mathrm{L}$, although this had little bearing on their achieved median $\mathrm{Hb}$ or median ESA dose when compared with other centres.

\section{Erythropoietin stimulating agents in prevalent haemodialysis patients}

As shown in previous reports there was substantial variation in the average dose of ESA prescription used. The median dose for prevalent HD patients in England, Wales and Northern Ireland was 7,450 IU/week and varied from 4,000 IU/week (Leeds) to 11,050 IU/week (Coventry). These results have been consistent over the last two years with a median $\mathrm{Hb}$ of $11.3 \mathrm{~g} / \mathrm{dl}$ and $10.8 \mathrm{~g} / \mathrm{dl}$ for Leeds and Coventry respectively (table 6.3). 
Table 6.4. Summary statistics for haemoglobin, serum ferritin and ESA for prevalent PD patients in 2011

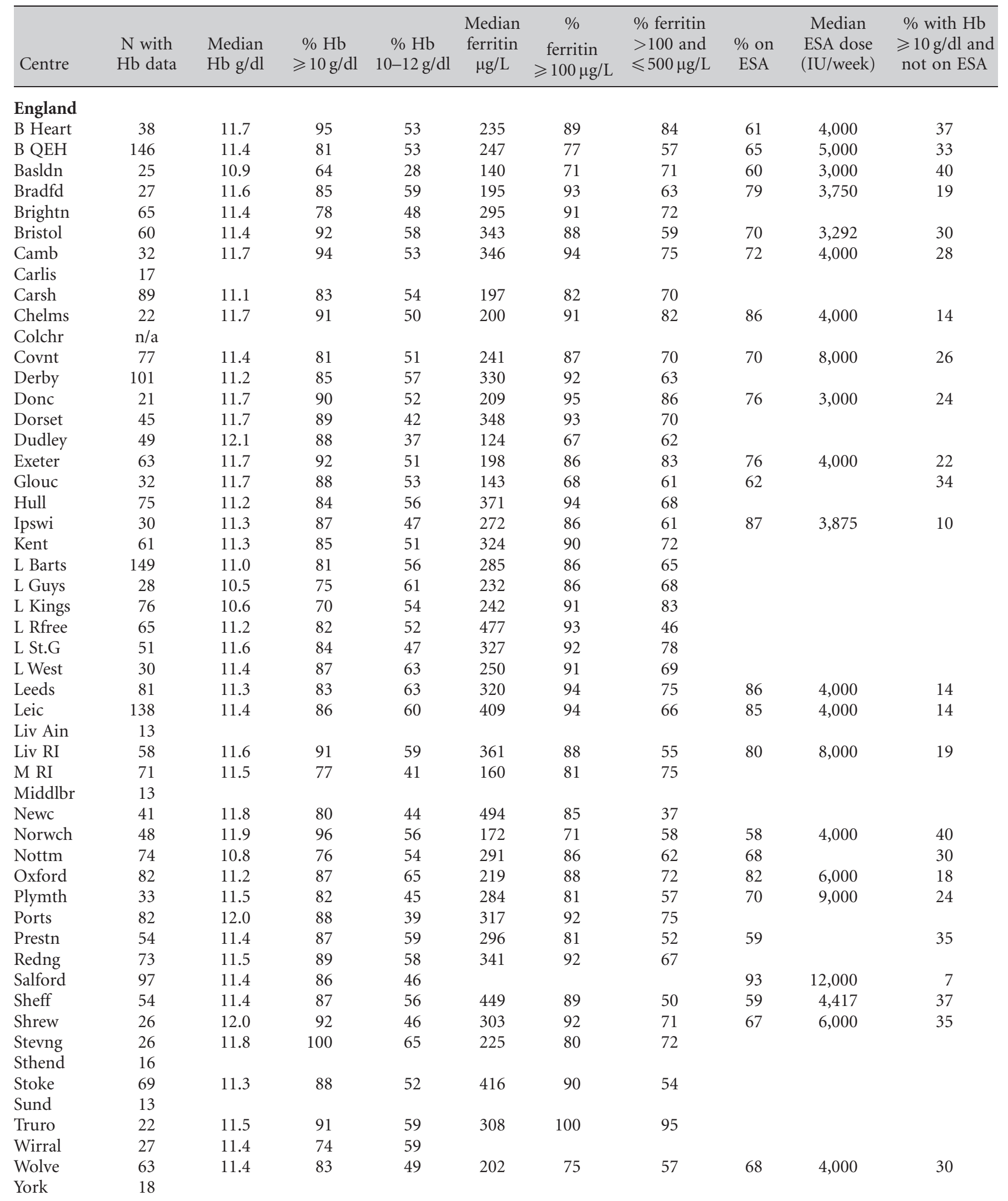


Table 6.4. Continued

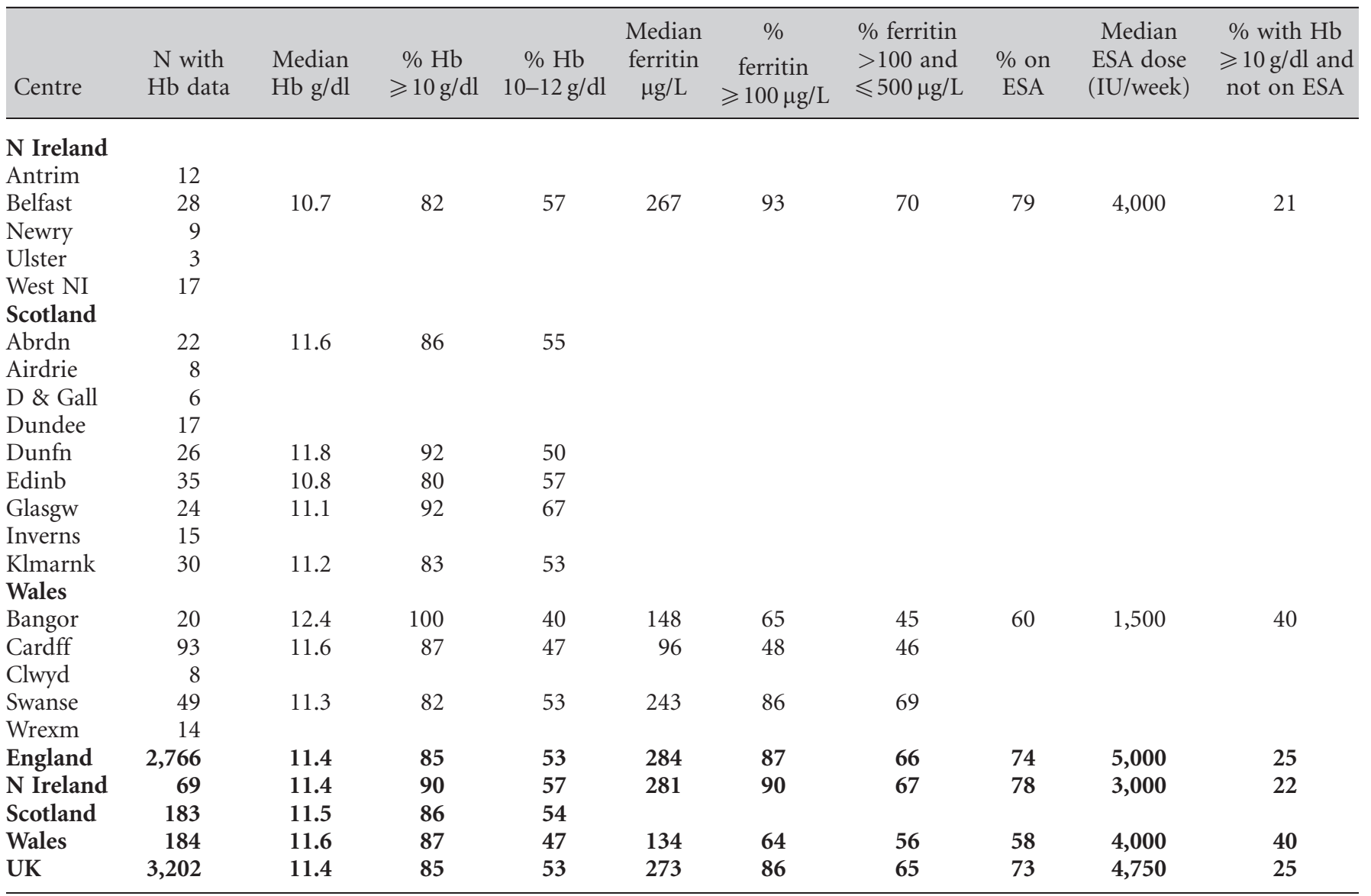

Blank cells - centres excluded from analyses due to poor data completeness or low patient numbers or because the data item was not available n/a - no PD patients

ESA data only shown for those centres for which the \% on ESA was $50 \%$ or more

For ferritin and for ESA the overall avaerages given are for E,W \& NI not UK

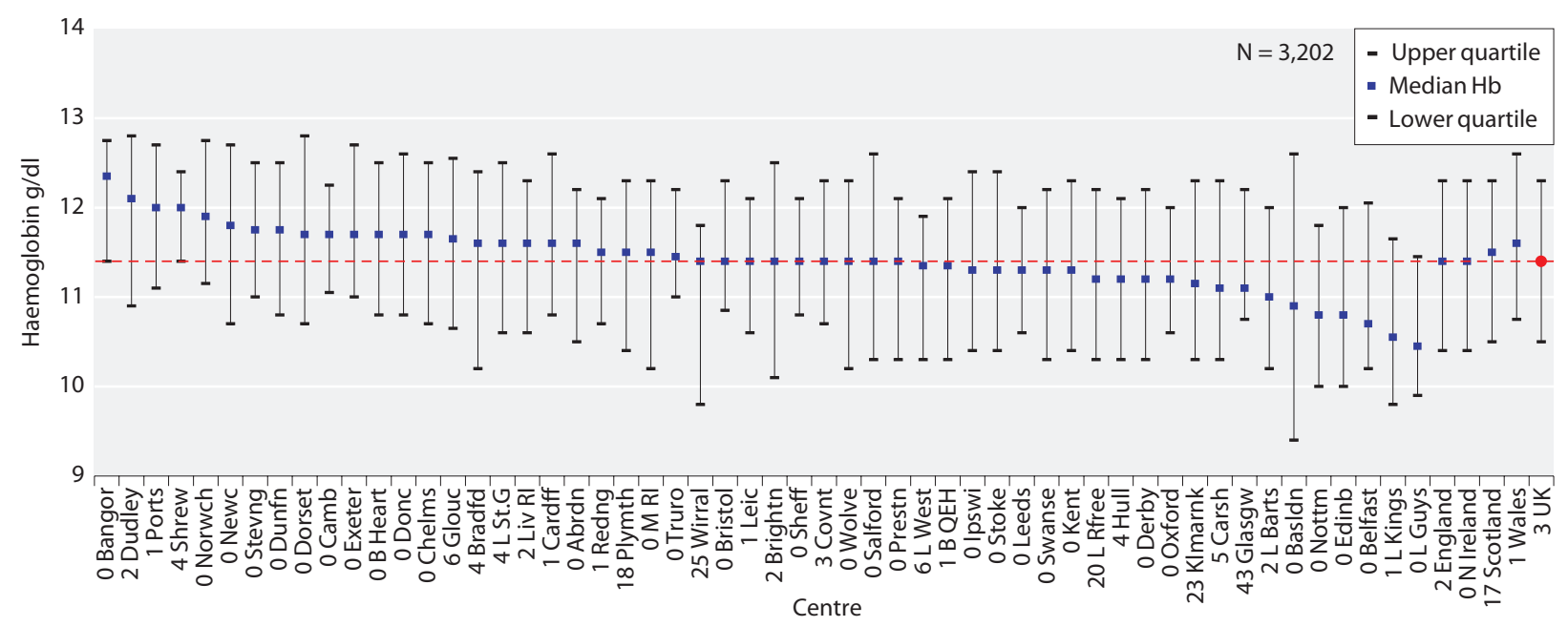

Fig. 6.12. Median haemoglobin in patients treated with PD by centre in 2011 


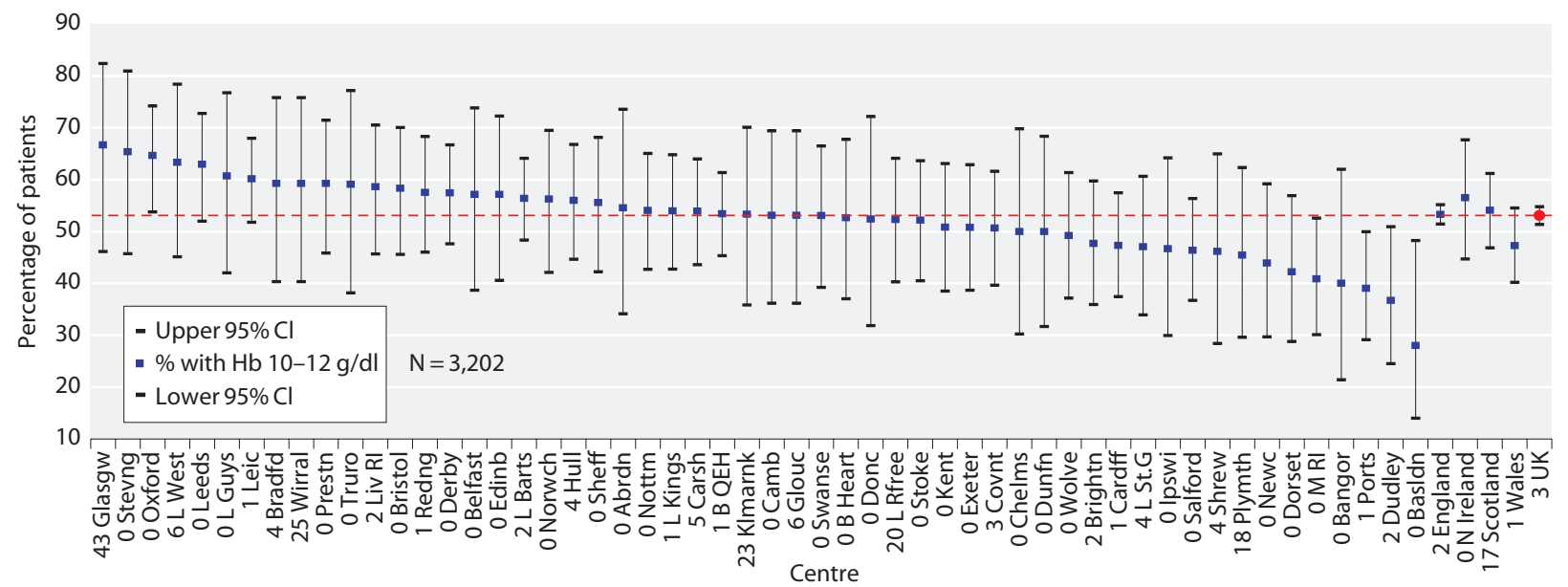

Fig. 6.13. Percentage of $\mathrm{PD}$ patients with $\mathrm{Hb} \geqslant 10$ and $\leqslant 12 \mathrm{~g} / \mathrm{dl}$ by centre in 2011

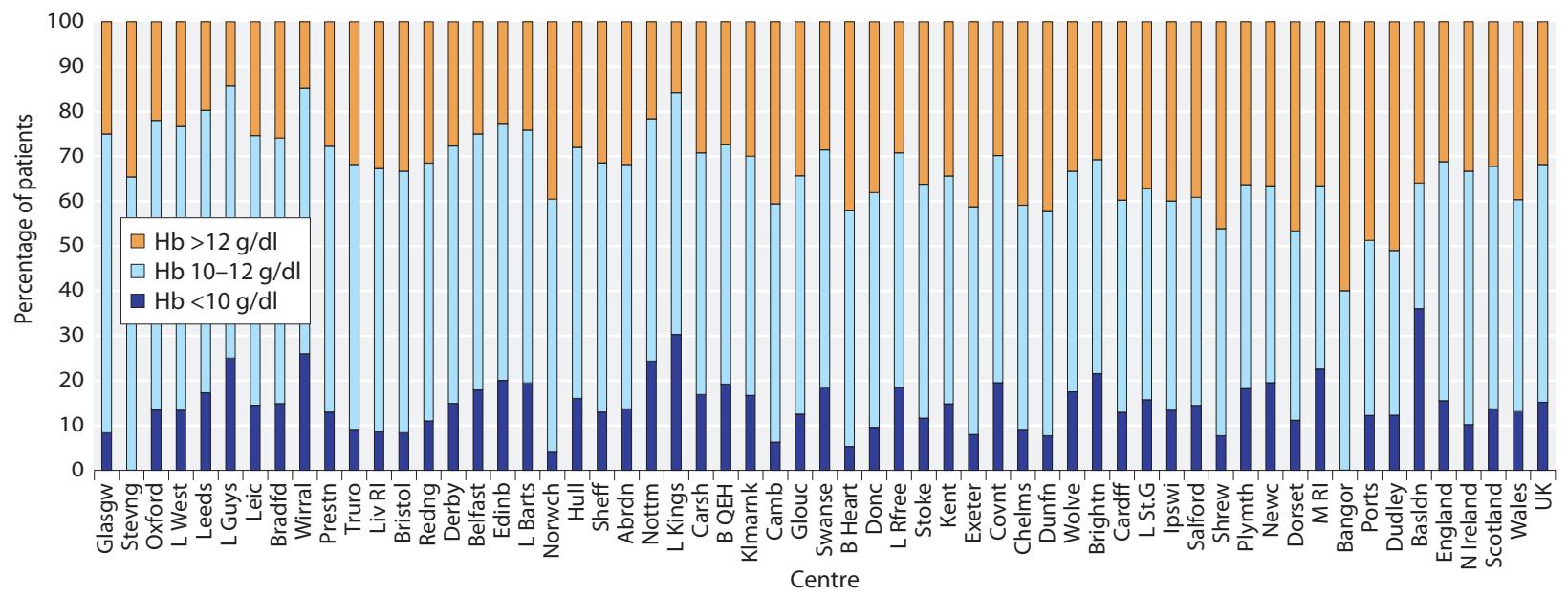

Fig. 6.14. Distribution of haemoglobin in patients treated with PD by centre in 2011

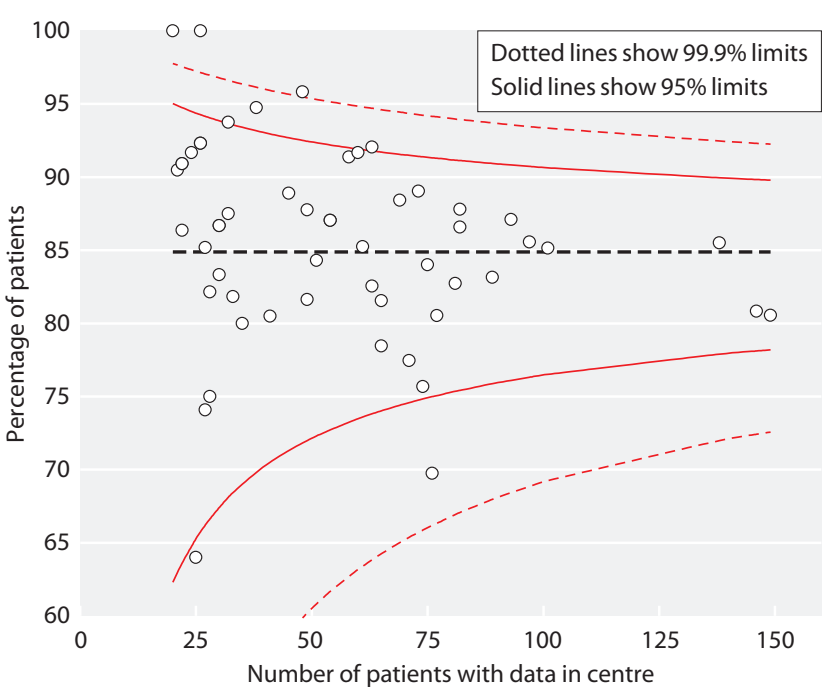

Fig. 6.15. Funnel plot of percentage of $\mathrm{PD}$ patients with $\mathrm{Hb}$ $\geqslant 10 \mathrm{~g} / \mathrm{dl}$ by centre in 2011

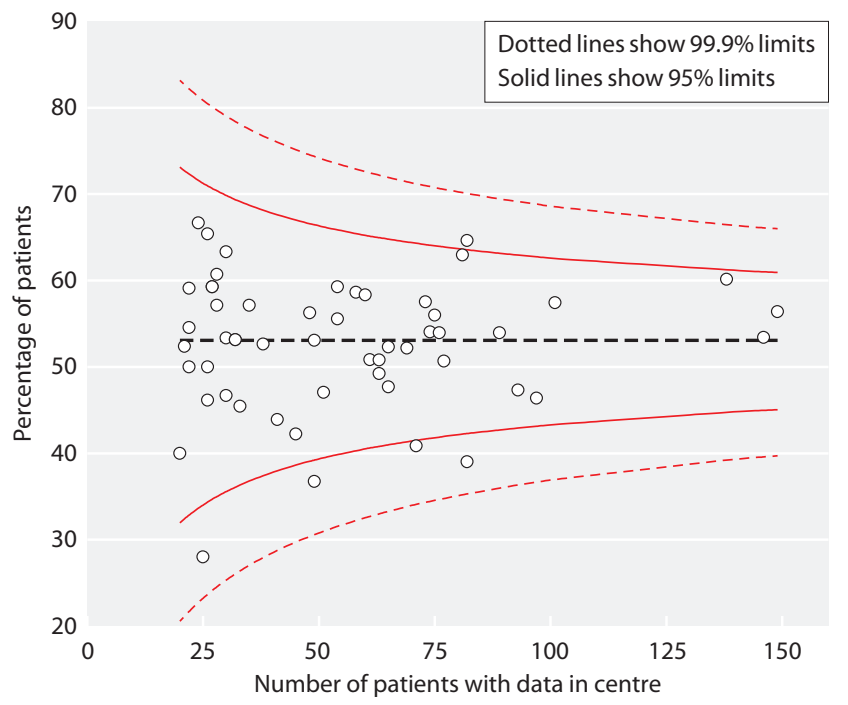

Fig. 6.16. Funnel plot of percentage of $\mathrm{PD}$ patients with $\mathrm{Hb}$ $\geqslant 10 \mathrm{~g} / \mathrm{dl}$ and $\leqslant 12 \mathrm{~g} / \mathrm{dl}$ by centre in 2011 


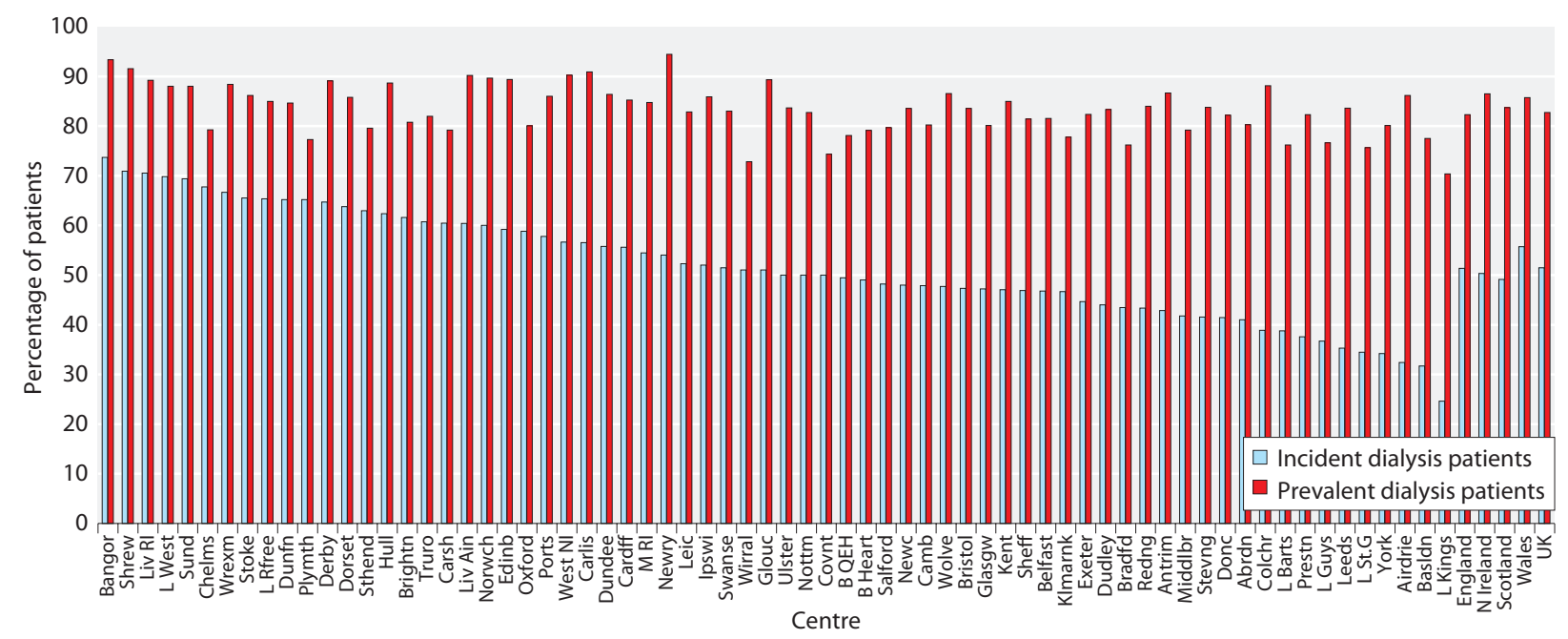

Fig. 6.17. Percentage of incident and prevalent dialysis patients with $\mathrm{Hb} \geqslant 10 \mathrm{~g} / \mathrm{dl}$ by centre in 2011

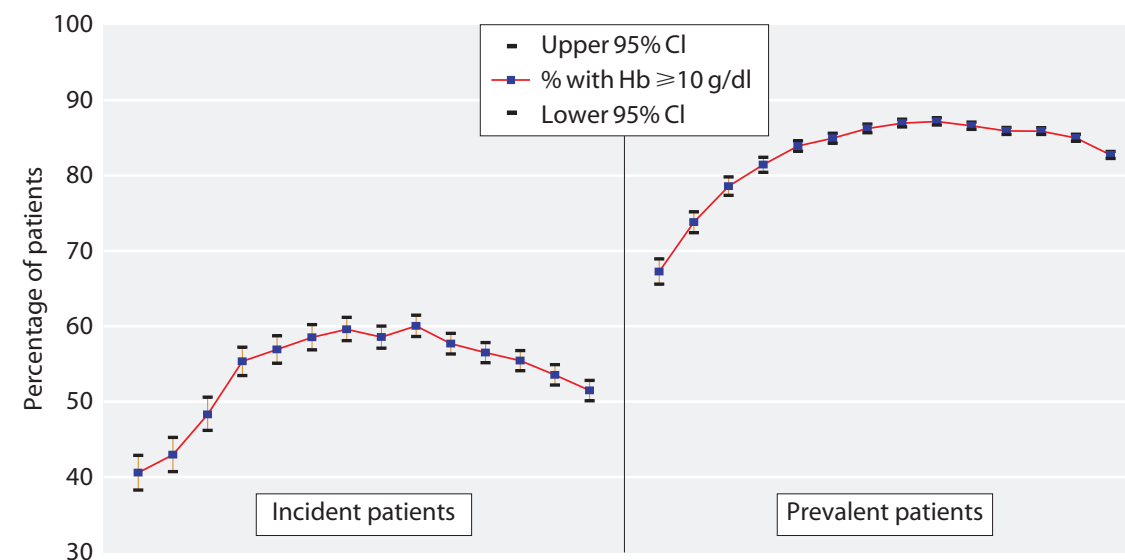

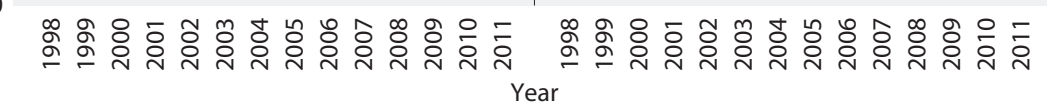

Fig. 6.18. Percentage of incident and prevalent dialysis patients (1998-2011) with $\mathrm{Hb} \geqslant 10 \mathrm{~g} / \mathrm{dl}$

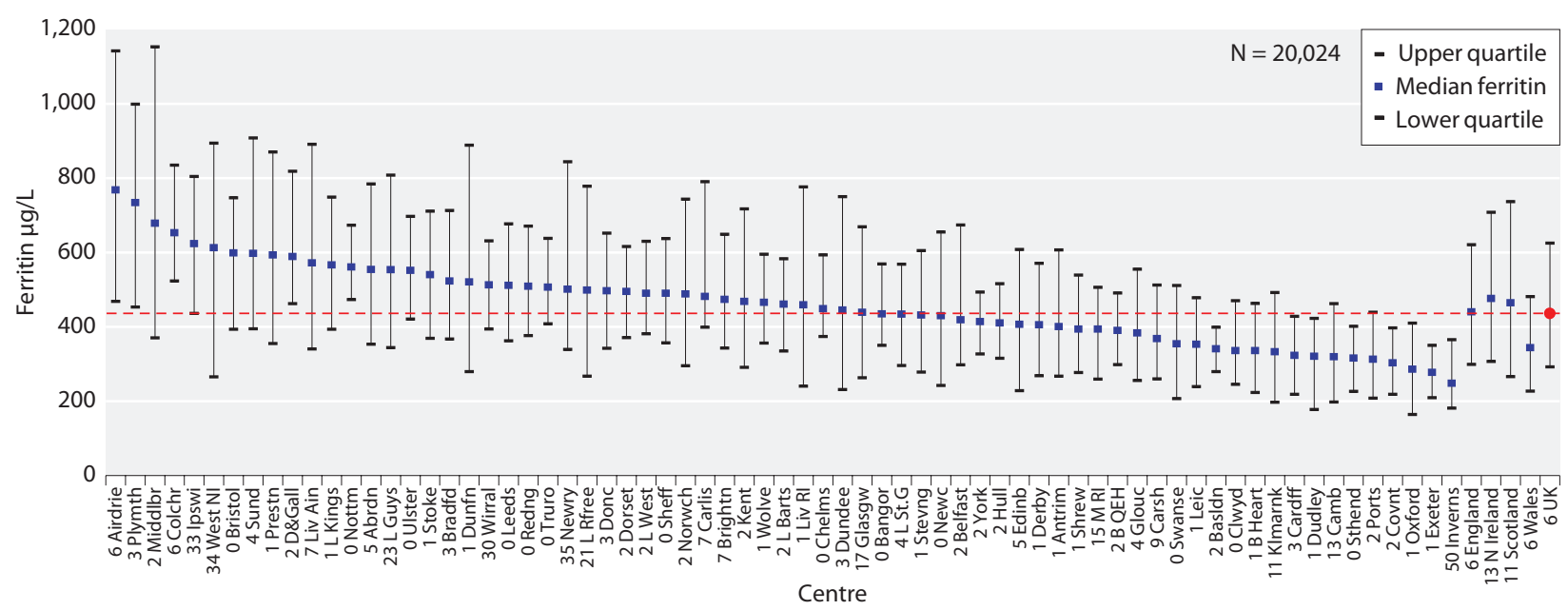

Fig. 6.19. Median ferritin in patients treated with HD by centre in 2011 


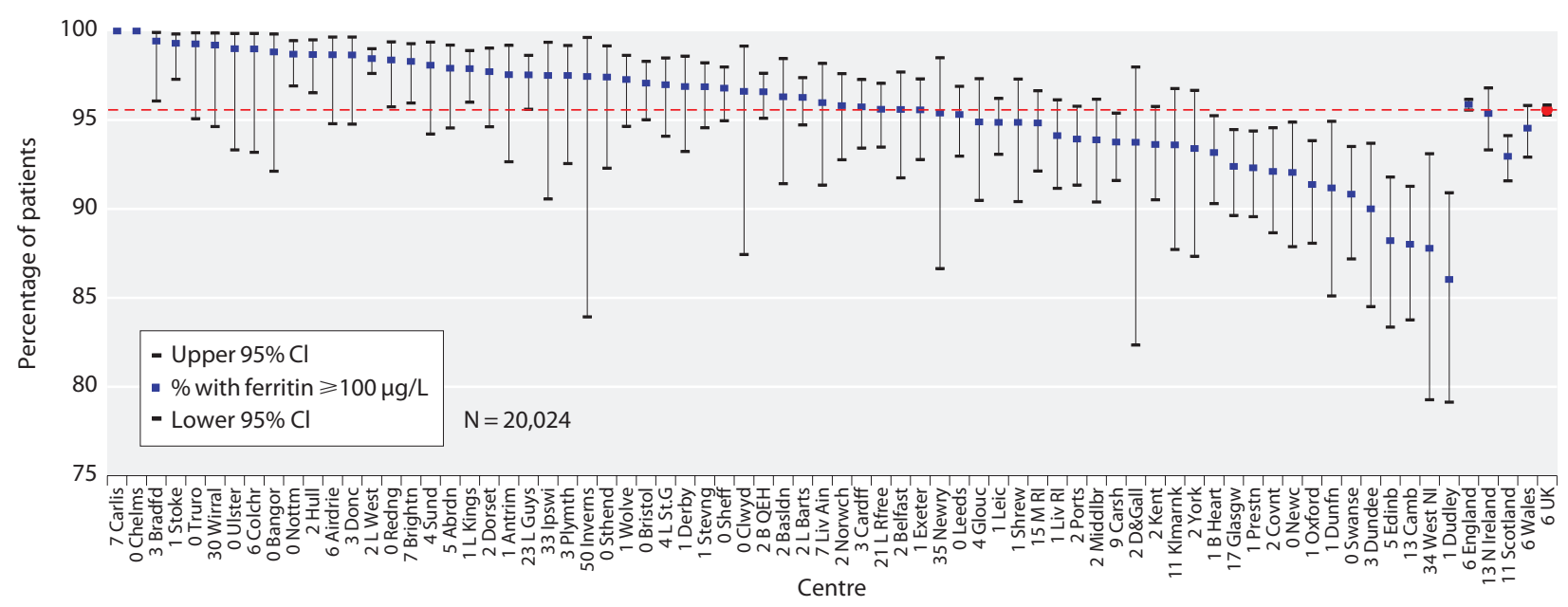

Fig. 6.20. Percentage of HD patients with ferritin $\geqslant 100 \mu \mathrm{g} / \mathrm{L}$ by centre in 2011

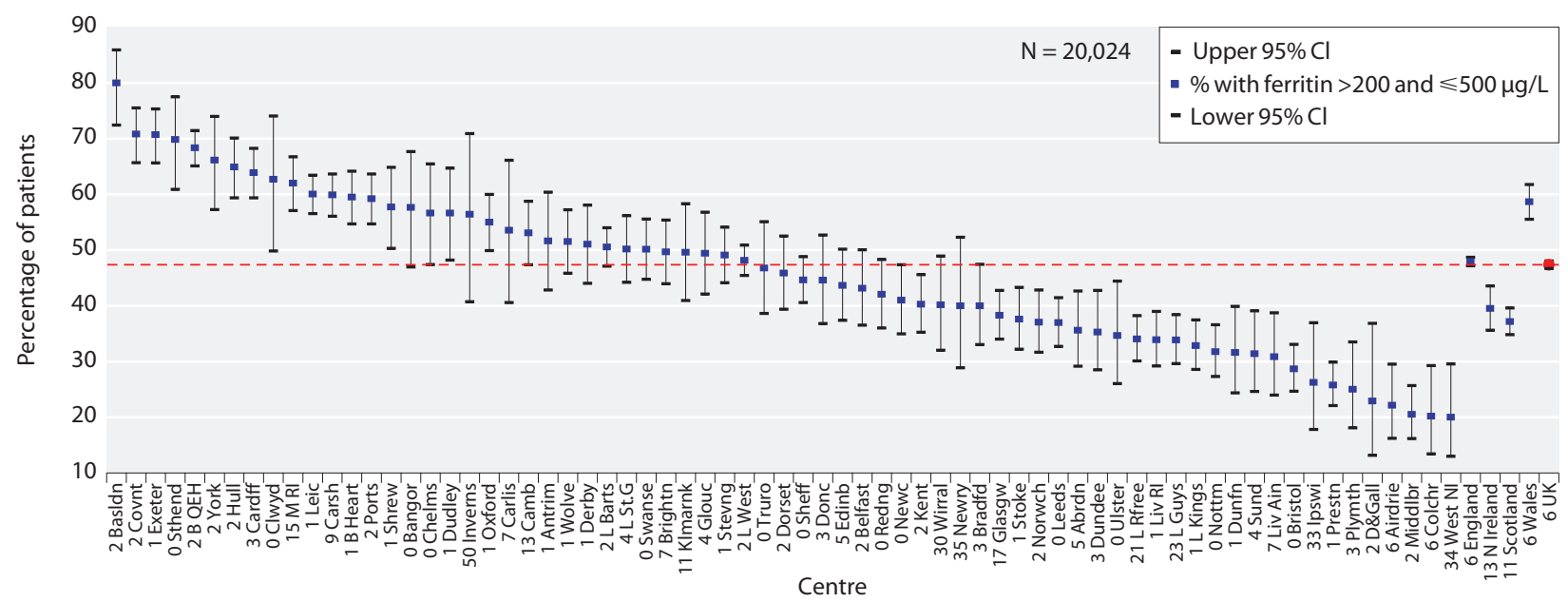

Fig. 6.21. Percentage of HD patients with ferritin $>200 \mu \mathrm{g} / \mathrm{L}$ and $\leqslant 500 \mu \mathrm{g} / \mathrm{L}$ by centre in 2011

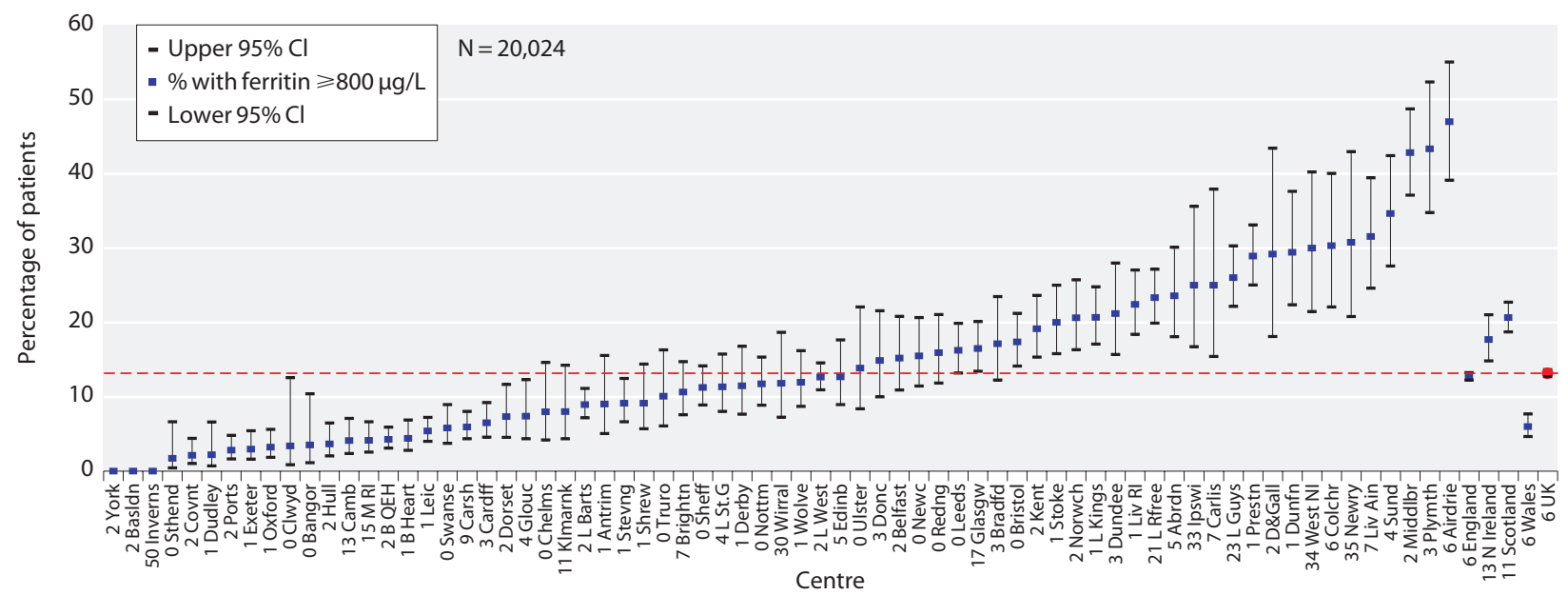

Fig. 6.22. Percentage of HD patients with ferritin $\geqslant 800 \mu \mathrm{g} / \mathrm{L}$ by centre in 2011 


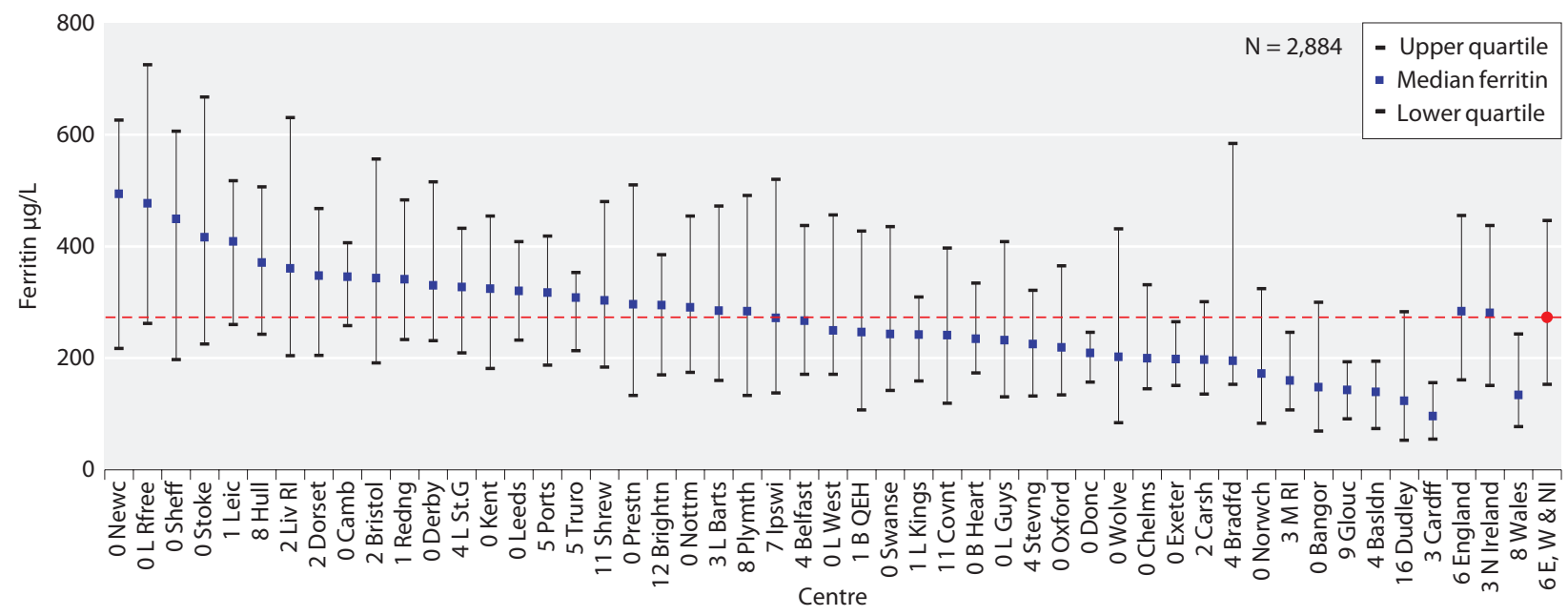

Fig. 6.23. Median ferritin in patients treated with PD by centre in 2011

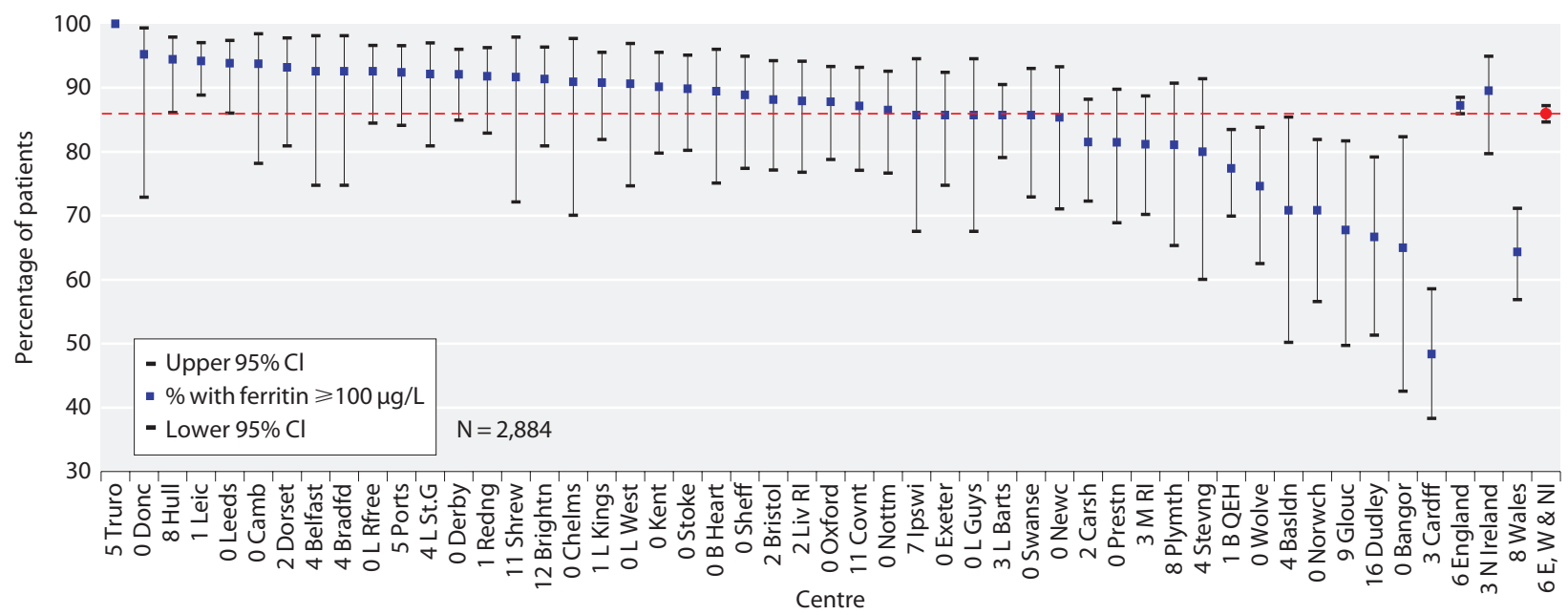

Fig. 6.24. Percentage of PD patients with ferritin $\geqslant 100 \mu \mathrm{g} / \mathrm{L}$ by centre in 2011

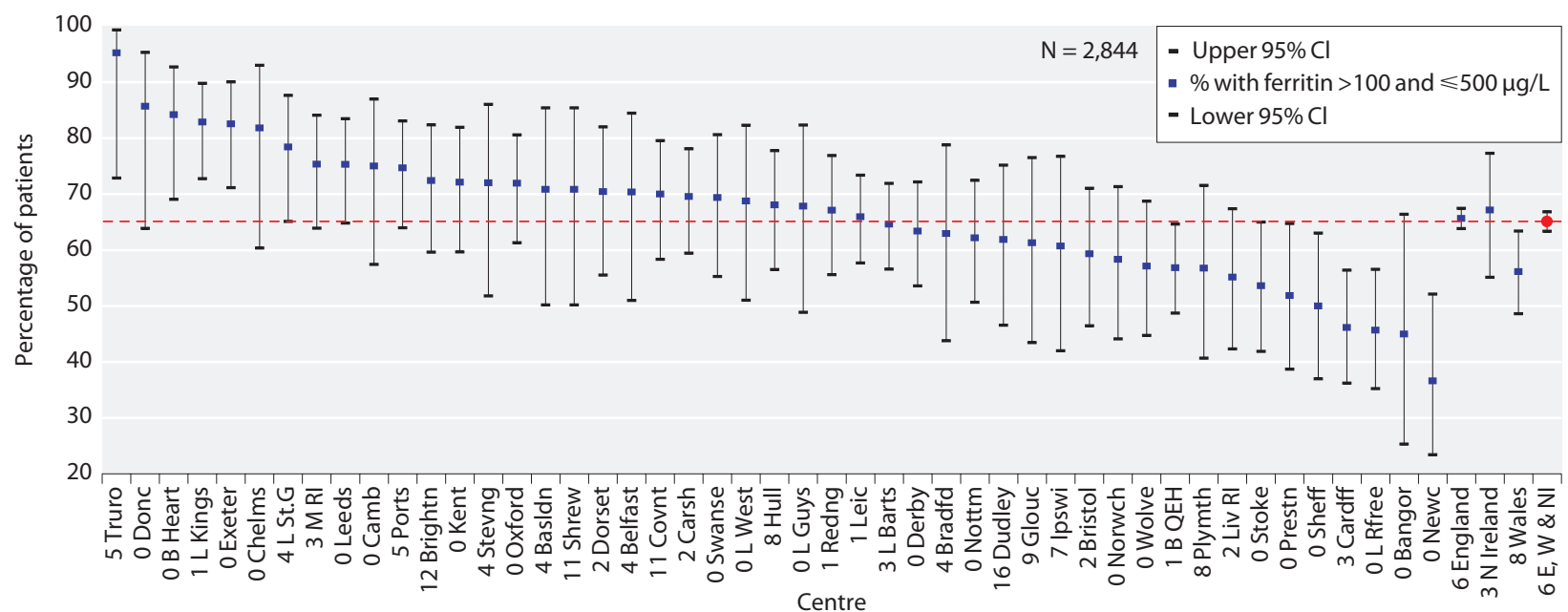

Fig. 6.25. Percentage of PD patients with ferritin $>100 \mu \mathrm{g} / \mathrm{L}$ and $\leqslant 500 \mu \mathrm{g} / \mathrm{L}$ by centre in 2011 


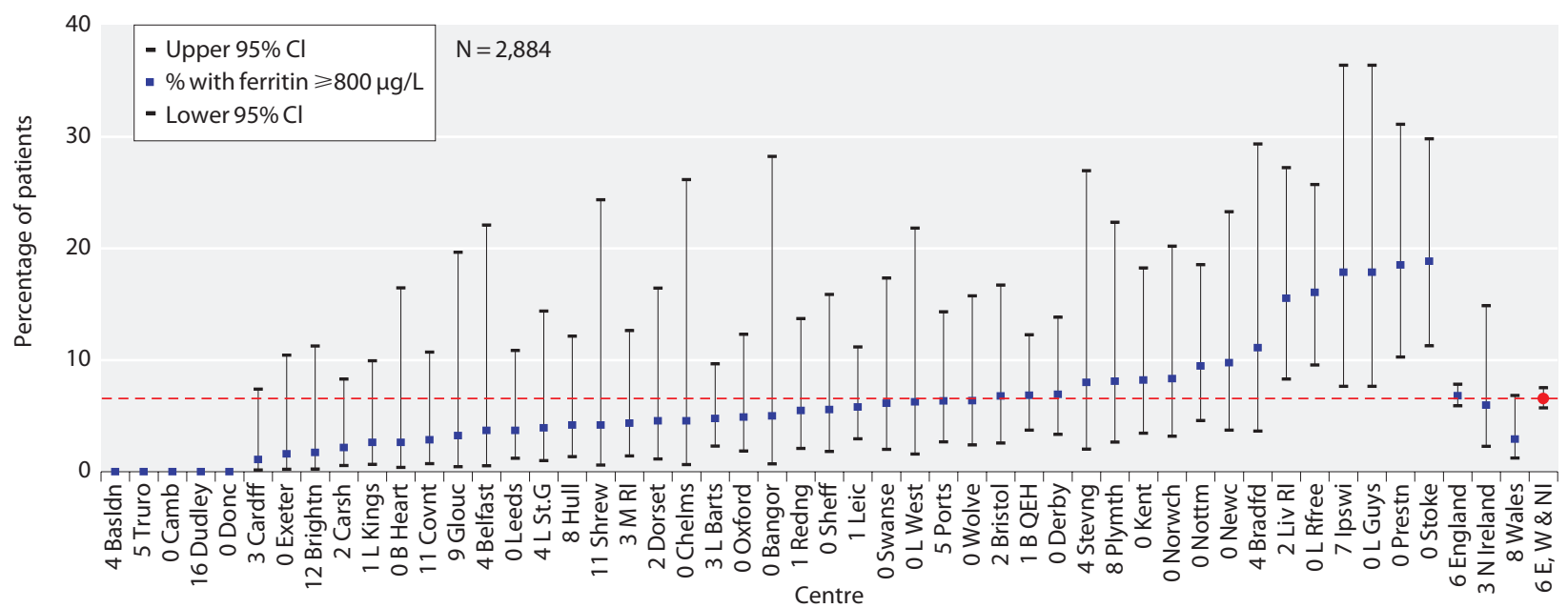

Fig. 6.26. Percentage of PD patients with ferritin $\geqslant 800 \mu \mathrm{g} / \mathrm{L}$ by centre in 2011

Erythropoietin stimulating agents in prevalent peritoneal dialysis patients

In 2011, the median dose was substantially lower in prevalent PD patients at 4,750 (range 1,500-12,000) IU/ week (table 6.4) compared to HD patients.

\section{ESA prescription: age and modality associations}

The proportion of patients on an ESA was higher for HD (90\%) than PD (73\%) and this difference was present and similar across all age groups (figure 6.27). The percentage of the whole cohort which maintained a $\mathrm{Hb} \geqslant 10 \mathrm{~g} / \mathrm{dl}$ without requiring ESA (by age group and modality) is shown in figure 6.28. This was highest at $12 \%(6-12 \%)$ in the $45-54$ age group for $\mathrm{HD}$ and highest for PD at 27\% (16-27\%) in the $75+$ age group.
Figure 6.29 shows the percentage of anaemic patients $(\mathrm{Hb}<10.0 \mathrm{~g} / \mathrm{dl})$ receiving an ESA. A minority of patients had a $\mathrm{Hb}<10 \mathrm{~g} / \mathrm{dl}$ and appeared to not be receiving ESA therapy. The Renal Association guidelines state that units should audit the "Proportion of patients on renal replacement therapy with $\mathrm{Hb}$ level $<10$ who are not prescribed an ESA". Across the age groups this was between $3-7 \%$ for HD patients and $3-16 \%$ for $\mathrm{PD}$ patients. There are several potential explanations for this. Treatment with ESA may have been stopped in some patients who were unresponsive or avoided in those with malignancy. Some patients may have recently become anaemic and not yet started therapy. Others may have been on ESA treatment but not had it recorded.

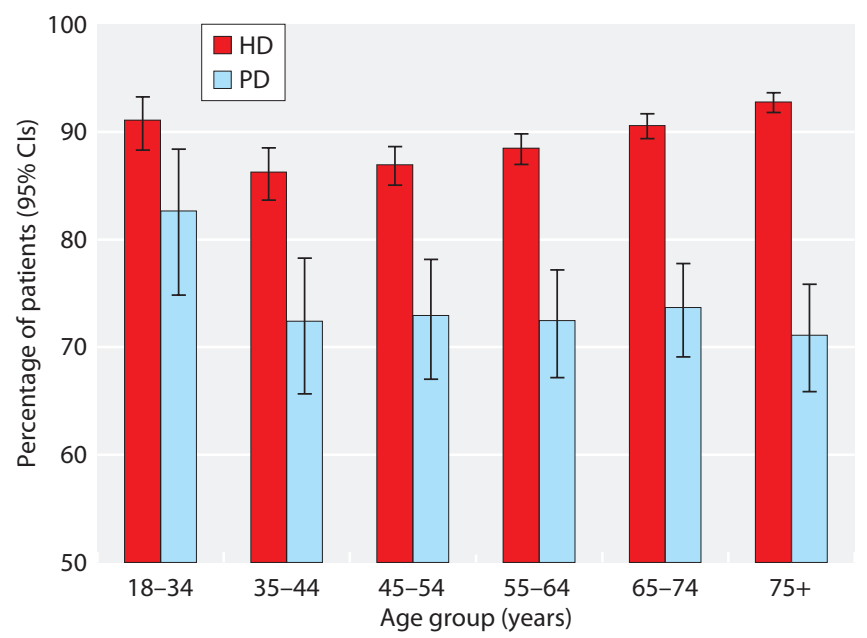

Fig. 6.27. Percentage of dialysis patients on ESA, by age group and treatment modality (2011)

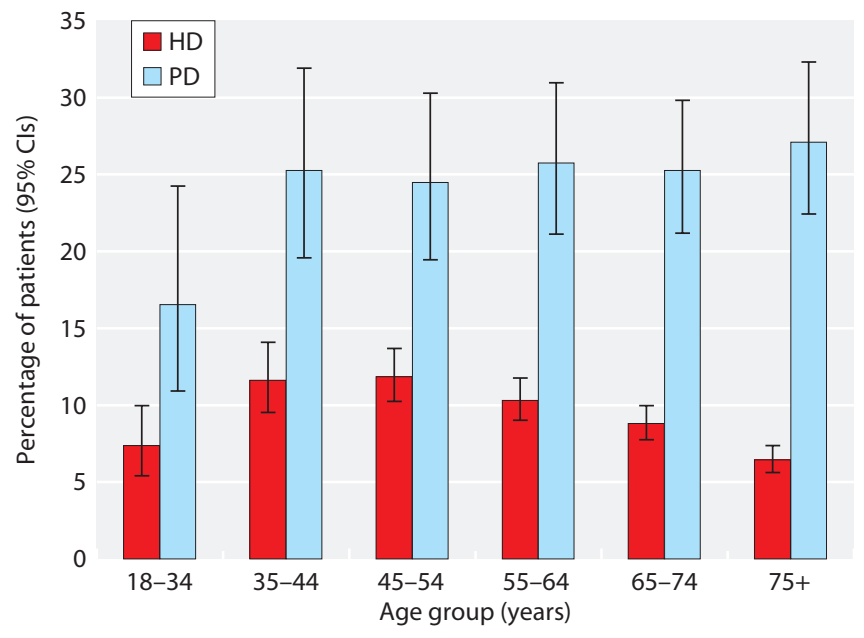

Fig. 6.28. Percentage of whole cohort (2011) who are not on ESA and have $\mathrm{Hb} \geqslant 10 \mathrm{~g} / \mathrm{dl}$, by age group and treatment modality 


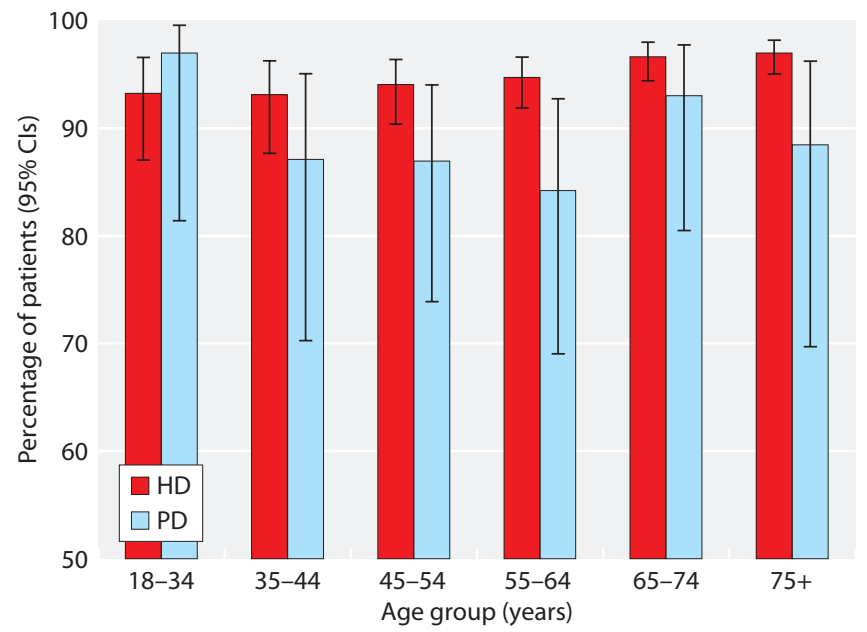

Fig. 6.29. Percentage of patients with $\mathrm{Hb}<10 \mathrm{~g} / \mathrm{dl}$ who are on ESA, by age group and treatment modality (2011)

\section{ESAs and time on renal replacement therapy}

The percentage of patients on ESA by time on RRT and dialysis modality is shown in figure 6.30. This is a cross-sectional analysis at the final quarter of 2011. Patients who had previously changed RRT modality were still included in this analysis. The proportion of PD patients requiring ESA rises with duration of RRT from $70 \%$ after $3-12$ months, to $80 \%$ after 10 or more years. This almost certainly reflects loss of residual renal function. For at least the first 10 years on RRT, a greater percentage of $\mathrm{HD}$ patients are receiving ESA treatment than patients on PD for any given duration on RRT.

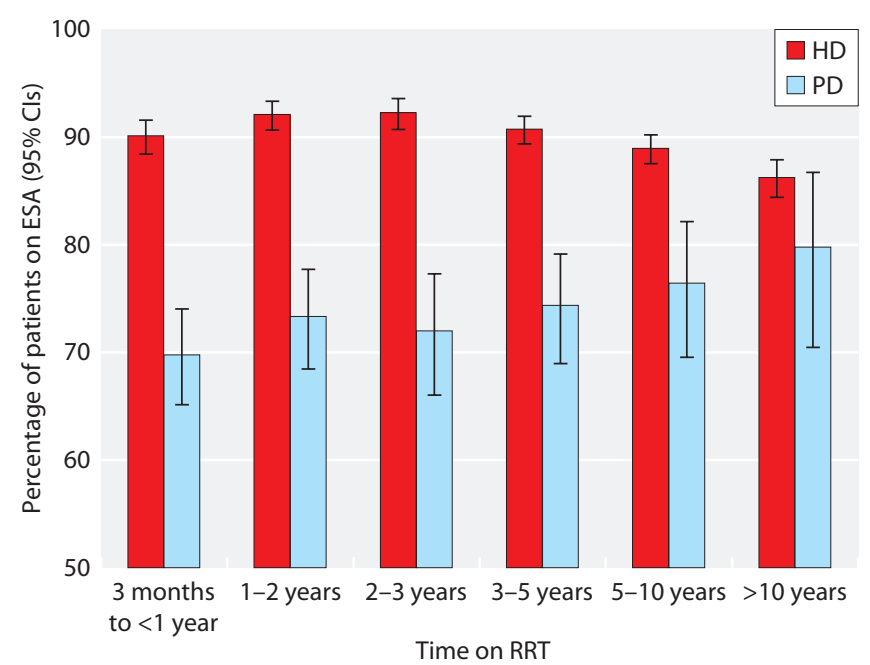

Fig. 6.30. Percentage of patients on ESA by time on RRT (2011)

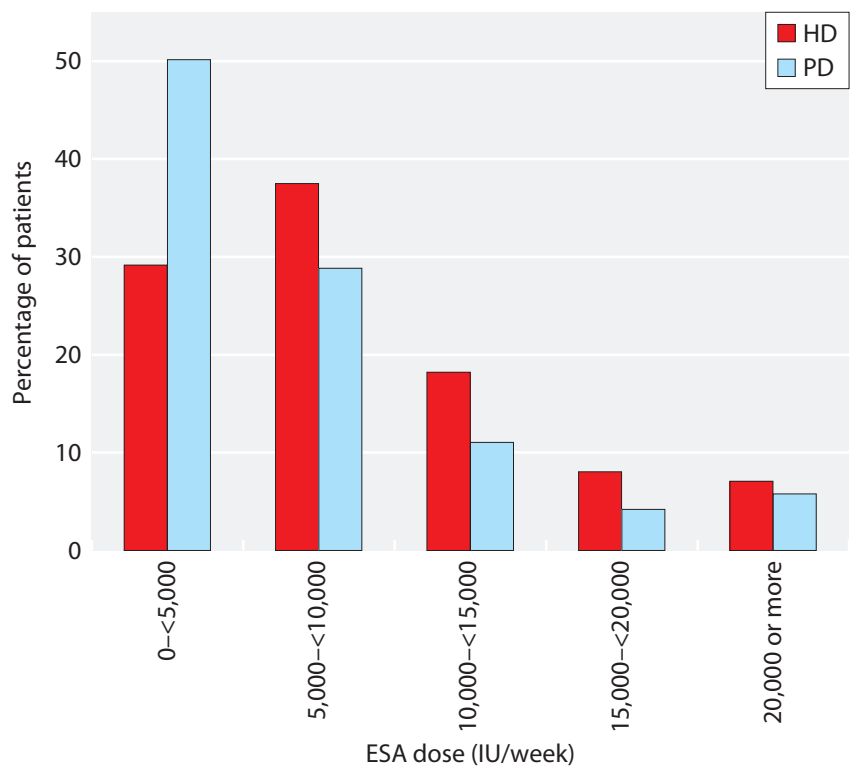

Fig. 6.31. Frequency distribution of mean weekly ESA dose in 2011

Resistance to ESA therapy

Figure 6.31 shows the frequency distribution of weekly ESA dose by treatment modality.

RA guidelines define resistance to ESA therapy as failure to reach the target $\mathrm{Hb}$ level despite SC epoetin dose $>300 \mathrm{IU} / \mathrm{kg} /$ week $(450 \mathrm{IU} / \mathrm{kg} /$ week IV epoetin) or darbepoetin dose $>1.5 \mathrm{mcg} / \mathrm{kg} /$ week. For a 70 kilo patient this equates to approximately $21,000 \mathrm{IU} /$ week for PD and 31,000 IU/week for HD. For those centres with good ESA completeness, the percentage of patients with EPO dose $>20,000 \mathrm{IU} /$ week was $5.8 \%$ and $7.1 \%$ for $\mathrm{PD}$ and $\mathrm{HD}$ respectively. In order to establish the true prevalence of ESA resistance in the UK, knowledge of patient weight and ESA dose will be needed.

\section{Success with guideline compliance}

Compliance with current minimum standards by year (1998 to 2011) is shown in figure 6.32 for prevalent patients (by treatment modality).

There is no strong relationship between centres' mean ESA dose and median $\mathrm{Hb}$ for $\mathrm{HD}$ patients (figure 6.33) or compliance with the RA standards for $\mathrm{Hb} \geqslant 10 \mathrm{~g} / \mathrm{dl}$ and $\leqslant 12 \mathrm{~g} / \mathrm{dl}$ in HD patients (figure 6.34). This is not surprising as the most anaemic patients and those least responsive to ESAs are those given the biggest doses.

It is known that not all patients treated with dialysis who have a $\mathrm{Hb}$ above $12 \mathrm{~g} / \mathrm{dl}$ are receiving ESA. It 


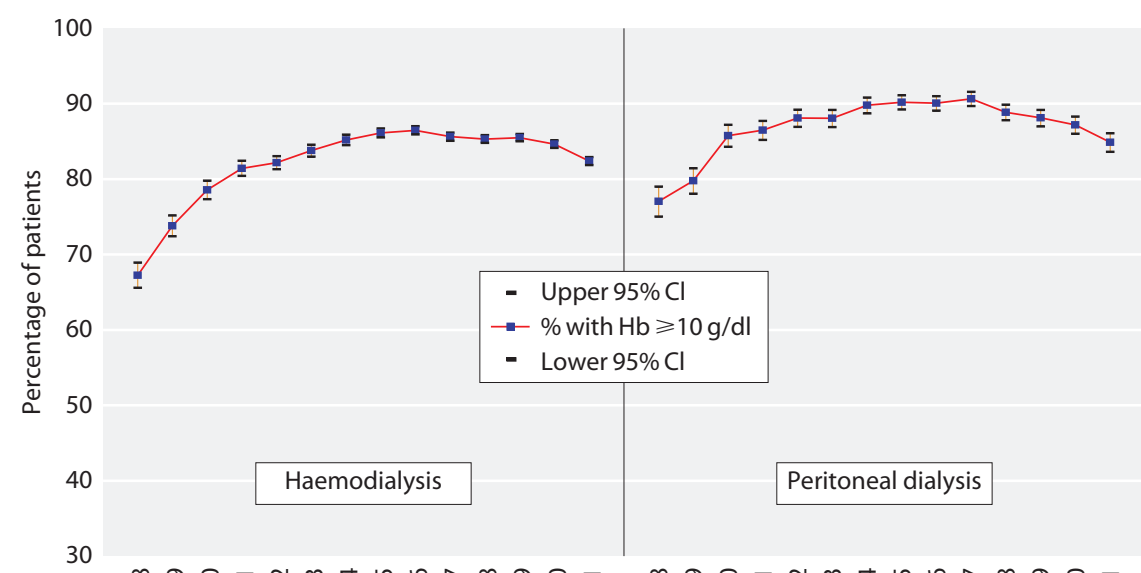

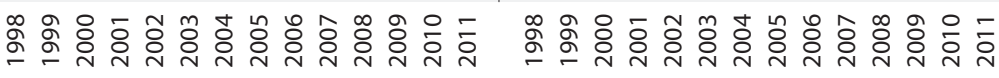

Fig. 6.32. Percentage of prevalent HD and $\mathrm{PD}$ patients (1998-2011) with $\mathrm{Hb}$ $\geqslant 10 \mathrm{~g} / \mathrm{dl}$

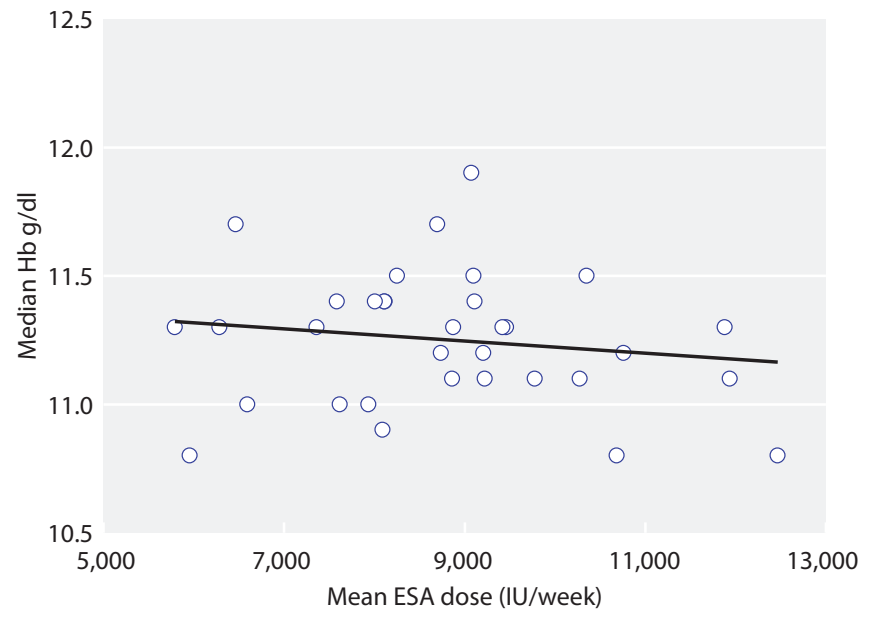

Fig. 6.33. Median $\mathrm{Hb}$ versus mean ESA dose in patients treated with HD by centre in 2011

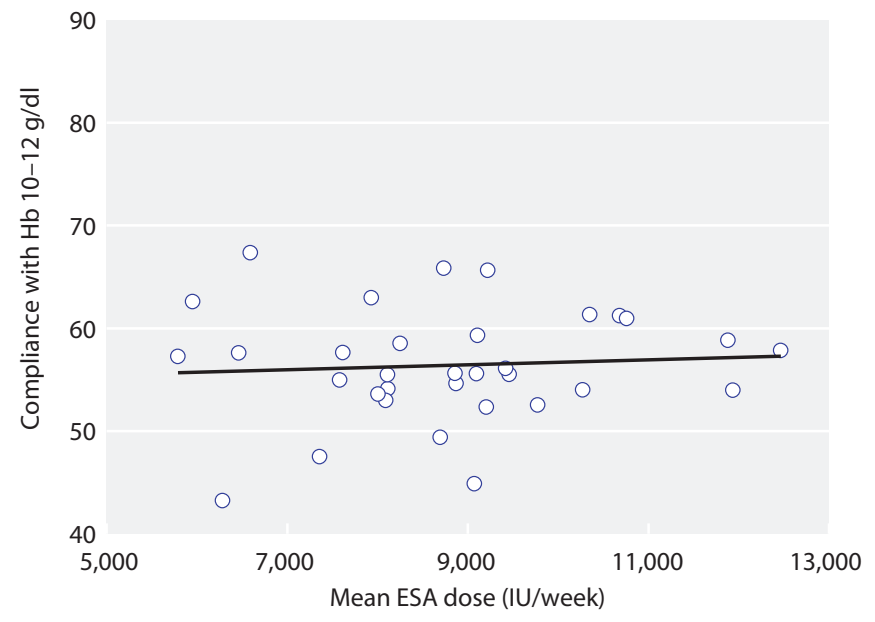

Fig. 6.34. Compliance with $\mathrm{Hb} 10-12 \mathrm{~g} / \mathrm{dl}$ versus mean ESA dose in patients treated with HD by centre in 2011

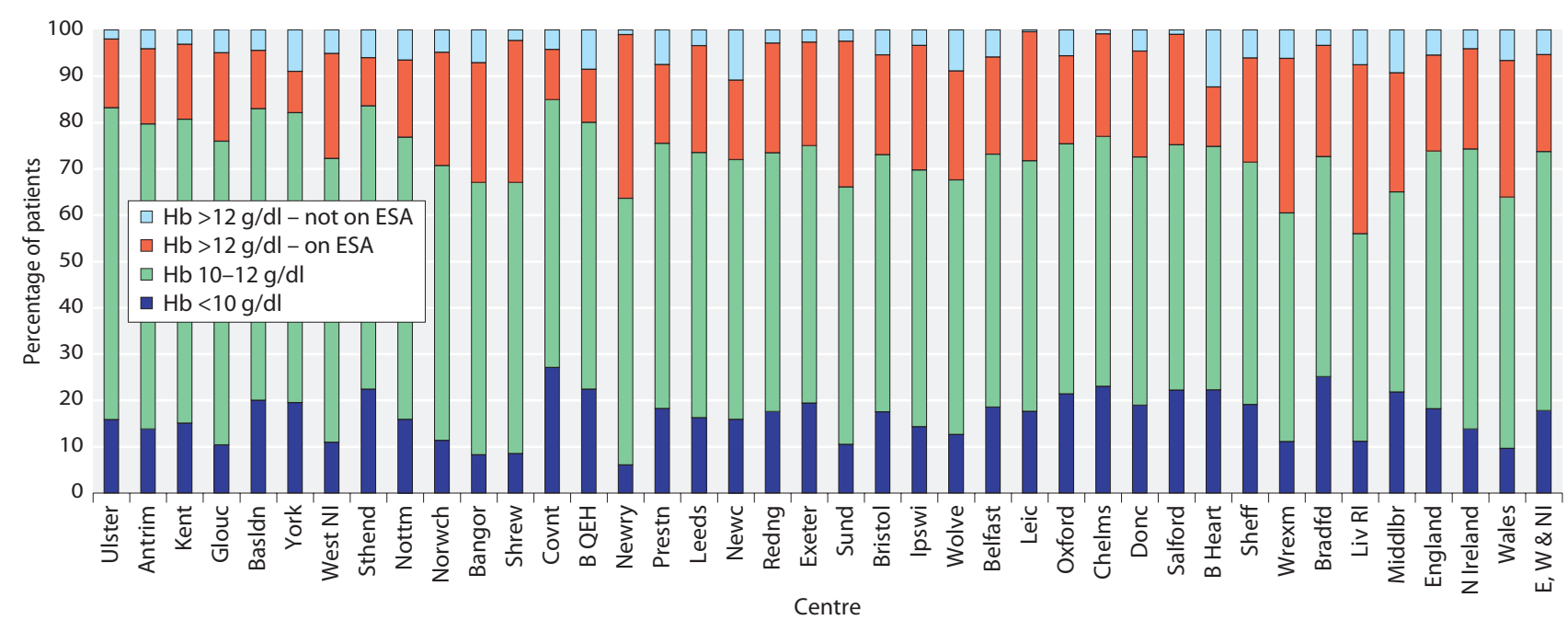

Fig. 6.35. Distribution of haemoglobin in patients treated with $\mathrm{HD}$ and the proportion of patients with $\mathrm{Hb}>12 \mathrm{~g} / \mathrm{dl}$ receiving ESA by centre in 2011 


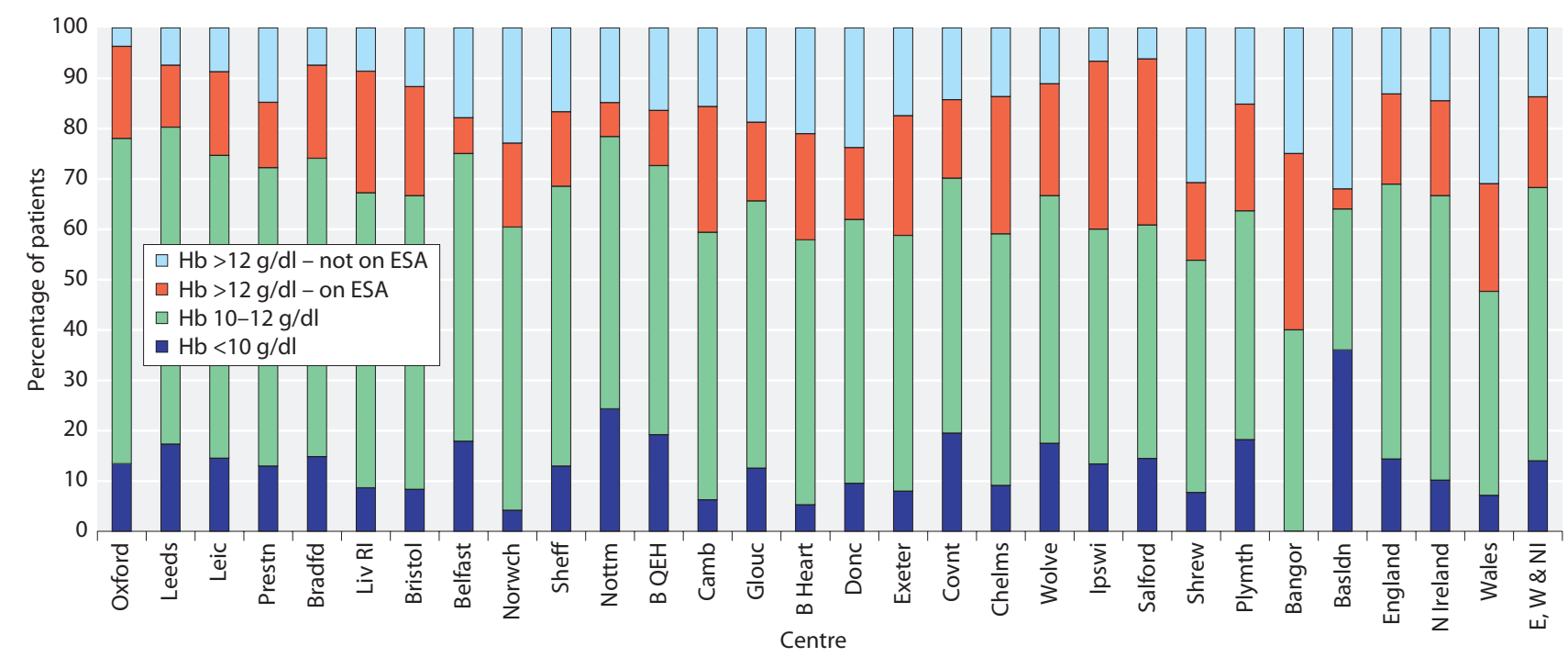

Fig. 6.36. Distribution of haemoglobin in patients treated with PD and the proportion of patients with $\mathrm{Hb}>12 \mathrm{~g} / \mathrm{dl}$ receiving ESA by centre in 2011

has been suggested that it may be inappropriate to include those patients not receiving ESA within the group not meeting this RA target. There are two reasons: firstly, the high $\mathrm{Hb}$ remains outside the control of the clinician, and secondly, the recent trials suggesting that it may be detrimental to achieve a high $\mathrm{Hb}$ in renal patients were based only upon patients treated with ESAs $[14,15]$.

Figures 6.35 and 6.36 show the percentages of HD and $\mathrm{PD}$ patients in each centre whose $\mathrm{Hb}$ lies above, within or below the RA guidelines of 10-12 g/dl. These charts also show the proportion of patients with a $\mathrm{Hb}$ above the upper limit who were receiving, or were not receiving ESAs. These analyses are restricted to the centres with acceptable ESA returns as stipulated above. These figures show that $26 \%$ of HD patients had a Hb $>12 \mathrm{~g} / \mathrm{dl}$. Most of these patients $(80 \%)$ were on ESAs. Whereas for PD, $32 \%$ of patients had a $\mathrm{Hb}>12.0 \mathrm{~g} / \mathrm{dl}$, but only $57 \%$ of these were on ESAs.

The Renal Association guideline states that units should audit the "Proportion of patients with serum ferritin levels $<100 \mu \mathrm{g} / \mathrm{L}$ with an ESA" \& "The proportion of patients treated with an ESA with $\mathrm{Hb}$ $>12 \mathrm{~g} / \mathrm{dl}$ ". Table 6.5 shows that the percentage of all patients treated with an ESA and having $\mathrm{Hb}>12 \mathrm{~g} / \mathrm{dl}$ ranged between $9-36 \%$ for $\mathrm{HD}$ and between $4-35 \%$ for PD. For HD, there was a small percentage of patients having ferritin levels $<100 \mu \mathrm{g} / \mathrm{L}$ and being on an ESA. The percentages were somewhat higher for PD.
Renal Association guidelines state that "Each renal unit should audit the type, route and frequency of administration and weekly dose of ESA prescribed". Table 6.6 shows the percentage completeness for type, route and frequency of administration for centres reporting ESA data. The completeness was generally good for drug type and dose but patchy for frequency and route of administration.

\section{Discussion}

Haemoglobin outcomes for patients on HD and PD in the UK were largely compliant with the RA minimum standard of $\mathrm{Hb} \geqslant 10.0 \mathrm{~g} / \mathrm{dl}$ ( $82 \%$ and $85 \%$ respectively). As would be anticipated, a greater proportion of prevalent patients $(83 \%)$ than incident patients $(51 \%)$ had a $\mathrm{Hb} \geqslant 10.0 \mathrm{~g} / \mathrm{dl}$ in 2011.

In the UK, the median $\mathrm{Hb}$ of patients on $\mathrm{HD}$ was $11.2 \mathrm{~g} / \mathrm{dl}$ with an IQR of 10.3-12.1 g/dl, and the median $\mathrm{Hb}$ of patients on PD was $11.4 \mathrm{~g} / \mathrm{dl}$ with an IQR of $10.5-12.3 \mathrm{~g} / \mathrm{dl}$.

Compliance with advice regarding iron stores as reflected by ferritin remained stable in the UK with $96 \%$ of HD patients and $86 \%$ of PD patients achieving a serum ferritin greater than $100 \mu \mathrm{g} / \mathrm{L}$.

The analysis of ESA usage was limited by incomplete data returns. From the available data, $90 \%$ of $\mathrm{HD}$ patients and $73 \%$ of PD patients were on ESA treatment in England, Wales and Northern Ireland. The percentage 
Table 6.5. Percentage of patients with serum ferritin levels $<100 \mu \mathrm{g} / \mathrm{L}$ and on ESA and percentage of patients with $\mathrm{Hb}>12 \mathrm{~g} / \mathrm{dl}$ and on ESA by modality

\begin{tabular}{|c|c|c|c|c|}
\hline \multirow[b]{2}{*}{ Centre } & \multicolumn{2}{|c|}{ HD } & \multicolumn{2}{|c|}{ PD } \\
\hline & $\begin{array}{c}\% \text { with } \mathrm{Hb}>12 \mathrm{~g} / \mathrm{dl} \\
\text { and on ESA }\end{array}$ & $\begin{array}{c}\% \text { with ferr }<100 \mu \mathrm{g} / \mathrm{L} \\
\text { and on ESA }\end{array}$ & $\begin{array}{c}\% \text { with } \mathrm{Hb}>12 \mathrm{~g} / \mathrm{dl} \\
\text { and on ESA }\end{array}$ & $\begin{array}{c}\% \text { with ferr }<100 \mu \mathrm{g} / \mathrm{L} \\
\text { and on ESA }\end{array}$ \\
\hline
\end{tabular}

\section{England}

B Heart

B QEH

13

Basldn

Bradfd

Bristol

Camb

Chelms

Covnt

Donc

Exeter

Glouc

Ipswi

Kent

Leeds

Leic

Liv RI

Middlbr

Newc

Norwch

Nottm

Oxford

Plymth

Prestn

Redng

Salford

Sheff

Shrew

Sthend

Sund

Wolve

York

N Ireland

Antrim

Belfast

Newry

Ulster

West NI

Wales

Bangor

Wrexm

N Ireland

Wales
England

E, W \& NI
13

24

22

22

11

23

22

19

27

16

23

28

36

26

17

24

17

19

17

24

24

23

31

10

31

24

9

16

21

35

15

23

26

33

21

22

30

21
21

11

4

19

22

25

27

16

14

24

16

33

12

17

24

17

7

18

21

13

33

15

15

22

16

2

0

2

0

1

$$
8
$$

0

35

11

$18 \quad 6$

195

$21 \quad 7$

18

0

8

14

5

8

6

3

22

7

4

1

4

11

4

9

13

12

2

0

5
Blank cells denote centres excluded from analyses due to poor completeness or small numbers with data 
Table 6.6. Percentage completeness for type, route and frequency of administration of ESA

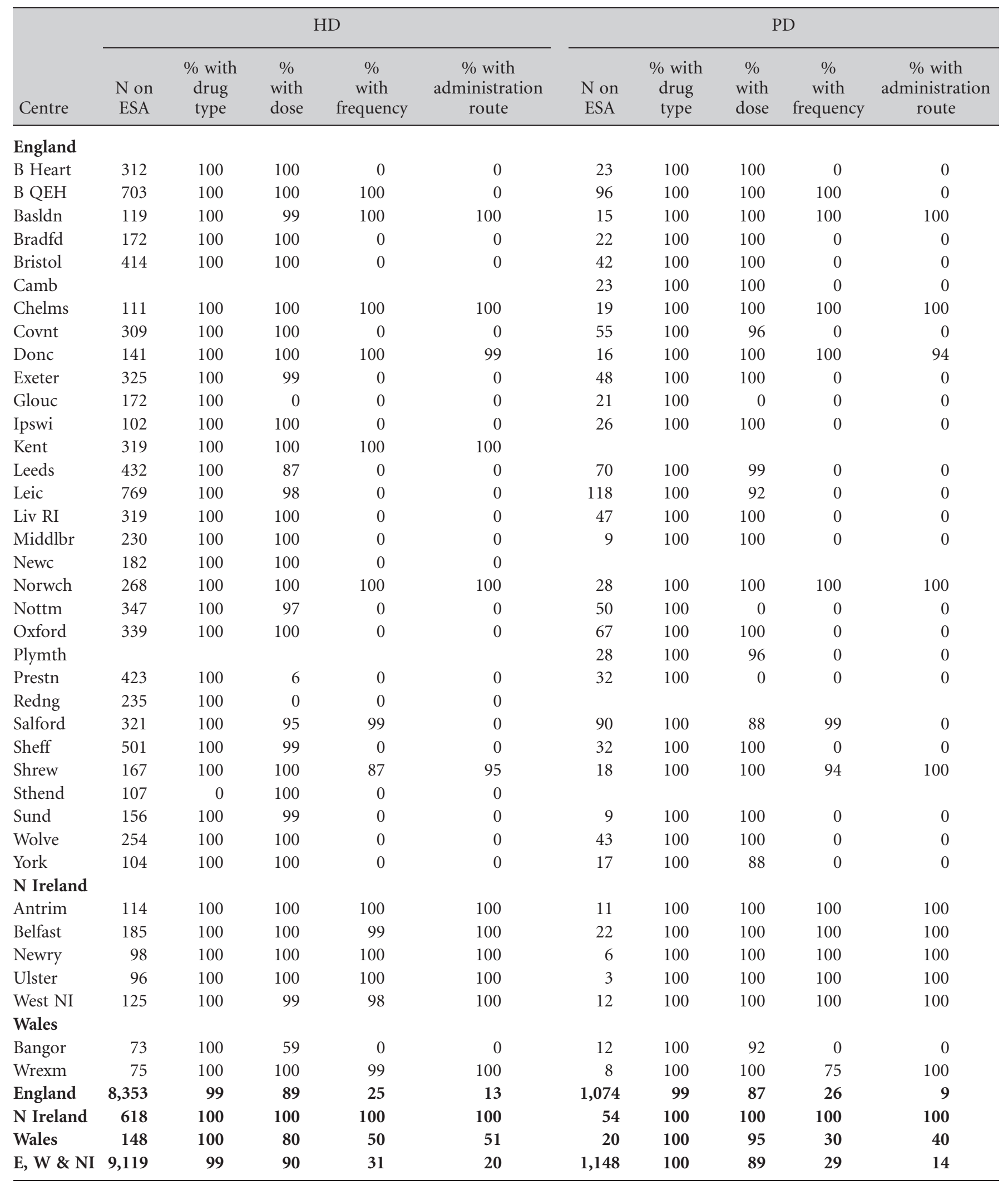


of patients treated with an ESA and having $\mathrm{Hb}>12 \mathrm{~g} / \mathrm{dl}$ ranged between centres from $9 \%-36 \%$ for $\mathrm{HD}$ and from $4 \%-35 \%$ for PD. There was a small percentage of patients with ferritin levels $<100 \mu \mathrm{g} / \mathrm{L}$ and receiving an ESA.

Conflicts of interest: none

\section{References}

1 KDIGO clinical practice guideline for anemia in chronic kidney disease. Summary of recommendations statements. Kidney International Supplements 2012;2:283-287

2 Department of Health Renal Team National Service Framework for Renal Services: Part One - Dialysis and transplantation, 2004, Department of Health: London

3 Renal Association. Treatment of adults and children with renal failure: standards and audit measures. 3rd Edition., 2002, Royal College of Physicians of London and the Renal Association: London

4 Revised European Best Practice Guidelines for the Management of Anaemia in Patients with Chronic Renal Failure. Nephrol Dial Transplant 2004;19:ii1-ii47

5 NKF-K/DOQI Clinical Practice Guidelines for Anemia of Chronic Kidney Disease: Update 2000. American journal of kidney diseases, 2001. 37(1): p. S182-S238

-6 National Collaborating Centre for Chronic Conditions. Anaemia management in chronic kidney disease: national clinical guideline for management in adults and children, 2006, Royal College of Physicians: London

7 Renal Association Clinical Practice Guidelines, 4th Edition. 2007 [cited 2008 15/9/2008]; 4th: [Available from: http://www.renal.org/pages/ pages/clinical-affairs/guidelines.php]
8 Renal Association Clinical Practice Guidelines Committee: Haemodialysis, 5th Edition. 2009. http://www.renal.org/clinical/guidelinessection/ haemodialysis.aspx

9 National Institute for Health and Clinical Excellence (NICE). Anaemia management in people with chronic kidney disease (CG114), 2011

$10 \mathrm{http} / /$ :www.kdigo.org

11 Movilli, E., et al., Predialysis versus postdialysis hematocrit evaluation during erythropoietin therapy. American journal of kidney diseases: the official journal of the National Kidney Foundation, 2002. 39(4): p. $850-853$

12 Kalantar-Zadeh, K., et al., Diagnosis of iron deficiency anemia in renal failure patients during the post-erythropoietin era. American Journal of Kidney Diseases, 1995. 26(2): p. 292-299

13 Singh, A.K., et al., Correction of Anemia with Epoetin Alfa in Chronic Kidney Disease. New England Journal of Medicine, 2006. 355(20): p. 2085-2098

14 Drüeke, T.B., et al., Normalization of Hemoglobin Level in Patients with Chronic Kidney Disease and Anemia. New England Journal of Medicine, 2006. 355(20): p. 2071-2084

15 Pfeffer, M.A., et al., A Trial of Darbepoetin Alfa in Type 2 Diabetes and Chronic Kidney Disease. New England Journal of Medicine, 2009. 361(21): p. 2019-2032 